\title{
Retroactivity, Reliability, and Due Process: A Reply to Professor Mishkin
}

\author{
Herman Schwartz
}

The judicially created revolution in criminal procedure dating from Mapp $v$. Ohio has thrown off numerous difficult problems of retroactivity. The Supreme Court has recently begun to grapple with these problems, ${ }^{1}$ and commentators, some of whom have long been fascinated by the "conflict of laws in time," have lately turned increasing attention to them..$^{2}$ One of the most important of the recent articles on this subject is Professor Paul Mishkin's The Supreme Court, 1964 Term Foreword: The High Court, the Great Writ and the Due Process of Time and Law. ${ }^{3}$ This article, an outgrowth of Professor Mishkin's earlier work on more general retroactivity issues, ${ }^{4}$ focuses on the applicability of newly enunciated due process standards to habeas corpus petitions filed by state prisoners whose convictions became final before the date of the enunciating decision. It concludes that unless the newly enunciated constitutional rights affect the reliability of the guilt-determining process, retroactivity should be denied.

Professor Mishkin's article is an important one not only because of the great power of the author's analysis, but also because it reflects a

Herman Schwartz, Professor of Law, State University of New York at Buffalo, received an A.B. degree in 1953 and an LL.B. degree in 1956 from Harvard University. The author wishes to express his deep appreciation to several of his colleagues and to Daniel Rezneck, Esq., for their extremely helpful, and often sharply critical, comments.

1 Johnson v. New Jersey, 86 Sup. Ct. 1772 (1966). Tehan v. United States ex rel. Shott, 382 U.S. 406 (1966); Linkletter v. Walker, 381 U.S. 618 (1965).

2 Among the many articles are Bender, The Retroactive Effect of an Overruling Constitutional Decision: Mapp v. Ohio, 110 U. PA. L. Rev. 650 (1962); Currier, Time and Change in Judge-Made Law: Prospective Overruling, 51 VA. L. REv. 201 (1965); Meador, Habeas Corpus and the "Retroactivity" Illusion, 50 VA. L. REv. 1115 (1964); Note, Linkletter, Shott and the Retroactivity Problem in Escobedo, 64 Mrch. L. REv. 832 (1966); Note, Prospective Overruling and Retroactive Application in the Federal Courts, 71 Yale L.J. 907 (1962); cf. Amsterdam, Search, Seizure and Section 2255: A Comment, 112 U. PA. L. REv. 378 (1964); Redlich, Constitutional Law, 1962 Survey of New York Law, 14 SYrACUSE L. Rev. 167, 170-72 (1962).

379 HARv. L. REv. 56 (1965) (hereinafter cited as Mishkin).

4 MISHKIn \& MORRIS, ON LAW IN CovRTS (1965). 
view widely held among both courts and commentators. ${ }^{5}$ This article will indicate possible shortcomings to the Mishkin approach in terms of utility, equality of treatment, consistency with prior decisions, and congruence with the current functions and operation of habeas corpus. It will argue that all newly declared constitutional rights should be given retroactive effect, because (1) the norms now being given federal constitutional sanction are not newly relevant, but rather so basic to our kind of constitutional democracy that convictions violative of them cannot be allowed to stand; and (2) the disadvantages of complete retroactivity have been greatly exaggerated.

\section{The Mishkin ApProach}

In Part I of his article, Professor Mishkin urges that for institutional, symbolic, and functional reasons, judicial decisions should almost always be accorded retroactive effect. Institutionally, courts exist to resolve past disputes, and adjudication thus inherently points retrospectively. Symbolically, and probably most importantly, much of the power and prestige of courts depends on the attribution of impartial impersonality to judges, who, under the Blackstonian conception, do not create but only declare "fixed overriding law"; 6 although this symbol of impartial and impersonal fidelity to preexisting law is often far from reality, abandoning it in favor of a general power of nonretroactive overruling would put the courts in the highly undesirable and politically vulnerable posture of overt legislators. Functionally, because retroactivity produces particularly strong reactions from those affected, judicial awareness that innovating decisions will have to be given retroactive effect may make for greater restraint.

Because of his general preference for retroactivity, Professor Mishkin deplores the fact that in Linkletter v. Walker the Supreme Court based its holding (that $M a p p$ is not available on habeas corpus to convictions which became final before the date of decision) on a "general power-and hence duty-to decide 'in each case' whether a rule

5 See, e.g., United States ex rel. Romano v. Fay, 360 F.2d 389 (2d Cir. 1966); Mordecai v. United States, 252 F. Supp. 694, 702-03 (D.D.C. 1966); In re Lopez, 62 Cal. 2d 368, 398 P.2d 380, 42 Cal. Rptr. 188 (1965); Commonwealth v. Negri, 419 Pa. 117, 213 A.2d 670 (1965); Bator, Finality in Criminal Law and Federal Habeas Corpus for State Prisoners, 76 HARv. L. REv. 441, 527 n.220 (1963); Weinstein, Some Difficulties in Devising Rules for Determining Truth in Judicial Trials, 66 CoLuM. L. Rev. 223, 228 n.23 (1966); Developments in the Law-Confessions, 79 HARv. L. REv. 938, 1013 (1966); Note, supra note 2, 71 YALE L.J. at 943.

6 Mishkin 62.

7381 U.S. 618 (1965). 
should be given retroactive effect." 8 The claim of such a general power is at war with the above-stated values, for it openly proclaims the legislative powers of the Court. Even on its own terms, Professor Mishkin further argues, the Linkletter decision was unwarranted. Although the Court noted that state officials had relied upon Wolf $v$. Colorado, ${ }^{9}$ such reliance was unjustified since Wolf had made it clear that at least the "core" of the fourth amendment was applicable to the states. Moreover, why should the benefit of retroactivity be given to Mrs. Mapp but not to Linkletter? The stated purposes of $M a p p$-deterrence of unconstitutional invasions of privacy and attainment of a more harmonious state-federal relationship-are furthered no more by retroactivity for Mrs. Mapp than for Linkletter, for in both cases "reparation comes too late." 10

For reasons he sets forth in Part III, however, Professor Mishkin concludes that both Mapp and Linkletter are not only right but also consistent with each other. Mrs. Mapp's case came up on direct review, and, in accordance with the normal preference for retroactivity, she received the benefit of the ruling, even if its rationale pointed prospectively. Linkletter's case, on the other hand, came up collaterally, on habeas corpus, and here:

The doctrine that a final judgment entered under a given rule of law may withstand subsequent judicial change in the rule is long established, and though that doctrine is perhaps more firmly settled in the context of civil litigation, the underlying considerations of finality find significant parallels in the criminal field. From this aspect, the Linkletter problem becomes not so much one of prospectivity or retroactivity of the rule but rather of the availability of collateral attack -in this case federal habeas corpus--to go behind the otherwise final judgment of conviction. ${ }^{11}$

For Professor Mishkin, collateral relief is extraordinary relief, justified in only two situations. The first he explains as follows:

$[R]$ ecognition of ... [constitutional defects in the procedure used to convict] serves to free prisoners as to whom there is greater doubt than the Constitution allows that they have in fact done the acts which constitute the crime for which they are being punished. 
[W] hen a constitutional guarantee is heightened or added to in a manner calculated to improve the reliability of a finding of guilt, the new interpretation essentially establishes a new required level of confidence as the condition for criminal punishment. ...

Valuing the liberty of the innocent as highly as we do, earlier proceedings whose reliability does not measure up to current constitutional standards for determining guilt may well be considered inadequate justification for continued detention .... On this basis, habeas corpus would assess the validity of a conviction, no matter how long past, by any current constitutional standards which have an intended effect of enhancing the reliability of the guilt-determining process. ${ }^{12}$

The second function of habeas corpus is to provide a substitute in the federal district courts for the unavoidably rare direct Supreme Court review of state decisions to enforce federal standards of dignity, integrity, and reliability. Insofar as the "intended effects" of a particular newly enunciated constitutional right are limited to furthering dignity and integrity and not reliability, Professor Mishkin contends, there is no reason to apply, on habeas corpus, standards that would not have been applied on direct review; upsetting old convictions cannot further these values.

Applying this analysis to specific cases, it is clear that $M a p p$ did not improve the reliability of the process, whereas Gideon $v$. Wainwright, ${ }^{13}$ Griffin v. Illinois, ${ }^{14}$ Griffin $v$. California, ${ }^{15}$ and Malloy $v$. $H_{o g a n^{16}}$ did. Coerced confessions likewise involve reliability, for coercion impairs, among other things, trustworthiness. Escobedo $v$. Illinois, ${ }^{17}$ however, "does not seem principally aimed at improving the trustworthiness of suspects' statements; protection of personal dignity and integrity, within the framework of an adversary system, seems a far more satisfactory rationale." 18

12 Id. at $80-82$.

13372 U.S. 335 (1963).

14351 U.S. 12 (1956). Professor Mishkin points out, however, that Griffin v. Illinois is an equal protection case, and that his concern is solely with procedural due process. Mishkin 83.

15380 U.S. 609 (1965). It is not altogether clear from Professor Mishkin's article whether he think that all aspects of the privilege against self-incrimination should be given retroactive effect. His discussion focuses on Griffin $v$. California, but he seems to indicate retroactivity should be accorded to the privilege in general.

16378 U.S. 1 (1964).

17378 U.S. 478 (1964).

18 Mishkin 95. 
The foregoing is Professor Mishkin's theory as I understand it. No summary, however, can do justice to the numerous subtle insights, or to the painstaking, balanced, and lucid comprehensiveness of his analysis. Nevertheless, with all deference, I think this approach contains too many difficulties to be workable and is fundamentally wrong.

\section{Some Problems with the Mishkin Approach The Inconsistency Between Parts I and III}

As previously mentioned, one of Professor Mishkin's major arguments against nonretroactive overruling is that it puts the Court into an overt legislative posture, thus exposing it to numerous political and doctrinal strains. But his own approach exposes the Court to precisely the same strains. Under his theory, the Court will have to make at least as many explicit and controversial decisions in respect to retroactivity as are necessary-and to him, deplorable-under a "general prospectivity power" theory. This is because every facet of every right "absorbed" into the fourteenth amendment will be raised on habeas corpus by some prisoner somewhere as soon as it is declared, and the Court will then have to make an overt, explicit choice between retroactivity and nonretroactivity. The fact that the issue arises on collateral attack some time after the right is first declared will not reduce the number of necessary choices, nor will the particular criterion by which retroactivity will be determined: once it is decided that only some rulings will be given retroactive effect, choices must openly be made, and it is the open display of change and of choice which exposes the legislative powers of the Court.

Indeed, where collateral attack is concerned, Professor Mishkin seems to swing almost completely away from his earlier preference for retroactivity, and to set up instead a presumption against retroactivity. Professor Mishkin proposes, as did the Court in Linkletter, that on collateral attack new standards not be applied to old convictions unless good cause is shown, i.e., unless reliability is involved. ${ }^{19}$ Thus, despite his earlier concern and criticism, he ends by putting the Court in the same undesirable legislative posture as he found and criticized in Linkletter. ${ }^{20}$

19 Compare Mishkin 77 with Linkletter: "[A]fter full consideration of all the factors we are not able to say that the Mapp rule requires retrospective application." 381 U.S. at 640. See also Tehan v. United States ex rel. Shott, 382 U.S. 406, 419 (1966).

20 The fact that Professor Mishkin would automatically apply the new law to cases on direct review which have not yet become final does not significantly reduce this presumption for prospectivity, for it is not uncommon for new legislation expanding individual rights to be applied to all cases still on direct review. Cf. Hamm v. City of Rock Hill, 379 U.S. 306 (1964) (passage of Civil Rights Act of 1964 abates all criminal trespass 
This alleged inconsistency will be of little concern to those who do not accept Professor Mishkin's symbolism rationale for preferring retroactivity. In addition, two aspects of the Mishkin approach might minimize the strains resulting from the exercise of a power of selective retroactivity: (l) making criminal due process decisions retroactive probably excites greater public hostility than does making them prospective; 21 (2) choosing between retroactivity and prospectivity by reference to whether a danger exists that innocent people were convicted by the use of unreliable evidence will probably excite relatively little public hostility. ${ }^{22}$

On the other hand, a theory which is hard to apply yet which must be applied frequently in controversial situations can often produce more dissatisfaction than one which, though initially less popular, is easier to apply. Apart from the unpopularity aspect-which, after all, cannot be given decisive weight-a theory of selective retroactivity raises the specter of continuous controversy over the soundness of its application.

\section{Shortcomings of the Reliability Test}

The reliability test's uncertainty, necessity for frequent application, and inadequacy for explaining recent decisions can best be seen by examining Professor Mishkin's analyses of three specific rights relating to the interrogation process: (1) the newly declared standards for determining when a confession is coerced, to which retroactive effect has apparently been given;23 (2) the privilege against self-incrimination with its no-comment corollary, to which retroactivity has just been

convictions still in the process of direct review); Bell v. Maryland, 378 U.S. 226, 230-32 (1964) (noting that the rule of abatement applies to any proceeding which, at the time of the supervening legislation, has not yet reached final disposition in the highest court authorized to review it, including the United States Supreme Court). See "saving clause" discussions in Hamm, 379 U.S. at 314, 319-20, and Bell, 378 U.S. at 232-37. Moreover, because a greater volume of cases will arise on collateral attack than are still on direct review, prospectivity will be invoked much more often than retroactivity.

21 It should be noted, however, that Professor Mishkin's general preference for retroactivity is based on a contrary hypothesis.

22 Even strongly prosecution-oriented critics purport to condemn police practices that raise doubts as to reliability. See Inbau \& ReId, Criminal Interrogation and Confessions 140-4I (1962).

23 Reck v. Pate, 367 U.S. 433 (1961). Although the point was not expressly discussed, the cases relied upon to set aside the conviction (e.g., Turner v. Pennsylvania, 338 U.S. 62 (1949)) were all decided well after Reck's original conviction in 1936. 367 U.S. at 442. The district court judge had denied relief because of this fact. See United States ex rel. Reck v. Ragen, 172 F. Supp. 734, 745 (N.D. Ill. 1959), aff'd, 274 F.2d 250 (7th Gir. 1960). 
denied;24 and (3) the Escobedo rule, the retroactivity of which has just been decided by the Supreme Court in Johnson v. New Jersey. ${ }^{25}$

\section{Coerced Confessions}

Professor Mishkin first notes that the Court "has made perfectly clear that the exclusion of [coerced] confessions does not depend upon any explicit finding or even any specific likelihood that the confession is unreliable." 26 Coercion does, however, produce a "significant risk" of unreliability, and "the constitutional rules may still have an intended effect upon the reliability of the guilt-determining process." 27 To meet the contention that the risk of unreliability under prior authority is so negligible as not to be a significant basis for the more recent confession rules, Professor Mishkin states: "It is in my judgment a complete answer . . . that the Supreme Court has ... continued consistently to develop its rationale in terms of 'coercion,' 'involuntariness,' and 'overbearing of the will' of the defendant. It seems appropriate to take the Court at its word."'28

Professor Mishkin's argument thus comes down to a reliance on the Court's continuing use of the "voluntariness" terminology. But if we are "to take the Court at its word," should we not take it at those words which fit the facts of the recent cases, rather than rely on a label like "voluntariness," which, as Professor Lawrence Herman has said, "hides the values now underlying the confession rules"?29 In Haynes v. Washington, ${ }^{30}$ Gallegos v. Nebraska, ${ }^{31}$ Spano v. New York, ${ }^{32}$ and the other recent confession cases, there was, as the Court itself indicated, no doubt as to the reliability of the confessions, nor is there in most coerced confession cases. Indeed, in Mapp Mr. Justice Clark stressed that "the right not to be convicted by use of a coerced confession [exists] however logically relevant it may be and without

24 Griffin v. California, 380 U.S. 609 (1965); Tehan v. United States ex rel. Shott, 382 U.S. 406 (1966).

2586 Sup. Ct. 1772 (1966). Analysis of the Court's decision appears in the Epilogue.

20 Mishkin 83.

27 Id. at 84 (emphasis added).

28 Id. at 84-85.

29 Herman, The Supreme Court and Restrictions on Police Interrogation, 25 Онго ST. L.J. 449, 457 (1964). For a thorough demolition of voluntariness as a meaningful criterion for these cases, see Kamisar, What Is an "Involuntary Confession": Some Reflections on Inbau and Reid's "Criminal Interrogation and Confessions," 17 RutGers L. REv. 729 (1963). See also Mapp v. Ohio, 367 U.S. 643, 656 (1961); Rogers v. Richmond, 365 U.S. 534, 540-41 (1961).

30373 U.S. 503 (1963).

31342 U.S. 55 (1951).

32960 U.S. 315 (1959). 
regard to its reliability," 33 and in Malloy 7 . Hogan, the Court made it clear that, as Professor Paulsen has said, "the true basis for excluding a coerced confession is not the danger of a false confession but the need to protect the defendant's privilege against self-incrimination." ${ }^{34}$ Protecting the privilege against self-incrimination is, as will be shown below, frequently more likely to impair rather than to foster reliability. Thus, if we really take the Court at its word, it becomes virtually impossible to base the retroactivity of the coerced confession cases on a realistic concern for reliability.

Professor Mishkin's view of the confession cases does find some modest support in Mr. Justice Clark's attempt in Linkletter to distinguish coerced confession from search and seizure cases. Mr. Justice Clark first denied that retroactivity was at issue at all in the confession cases: "[T] he principle that a coerced confession is not admissible in a trial predated the arrest as well as the original conviction in each of [Reck v. Pate and Fay v. Noia] . . ."35 He then went on to say that reliability and "the abhorrence of society" to coerced confessions also underlie exclusion, citing only Jackson v. Denno ${ }^{36}$ for the reliability point. ${ }^{37}$ Because "there is no likelihood of unreliability or coercion present in a search and seizure case," he concluded, the confession cases are inapposite. ${ }^{38}$

33367 U.S. at 656 . The irrelevance of reliability to the voluntariness doctrine was noted many years ago. See, e.g., Rochin v. California, 342 U.S. 165, 172-74 (1952); Lisenba v. California, 314 U.S. 219, 236 (1941); Allen, The Wolf Case: Search and Seizure, Federalism, and Civil Liberties, 45 ILL. L. REv. I, $26-29$ (1950); McCormick, Some Problems and Developments in the Admissibility of Confessions, 24 TEx. L. REv. 239, 240-45 (1946). For more recent confirmation, see Jackson v. Denno, 378 U.S. 368, 386 (1964); Rogers v. Richmond, 365 U.S. 534, 540-41 (1961) (consideration of truth or falsity is "irrelevant and impermissible" in determining voluntariness, for involuntary confessions are excluded "because the methods used ... . offend ... [an] underlying principle .. . that ours is an accusatorial and not an inquisitorial system.")

There is, however, a real danger of partial unreliability. See Herman, supra note 29, at $454 \mathrm{n} .25$. Indeed, one interrogator has confided to me that he sometimes wonders how any confession stands up because though confessions are basically accurate, the transcription process and the frequent absence of a stenographer, which necessitates direct and laborious typewriter transcription by a policeman, make for numerous inaccuracies in detail. Weakness of memory and the tensions of the moment would also seem to preclude total accuracy. The Court, however, has rarely mentioned such problems, and this kind of partial inaccuracy, which would rarely raise significant doubts as to guilt, would hardly be enough to justify the now extensive "voluntariness" limits on interrogational techniques.

34 Paulsen, The Winds of Change: Criminal Procedure in New York 1941-1965, 15 BuFF. L. REv. 297, 301 (1966); see Malloy v. Hogan, 378 U.S. 1, 5-9 (1964).

35381 U.S. at 638.

36378 U.S. 368 (1964).

37381 U.S. at 639 n.20.

38 Id. at 638. 
Mr. Justice Clark's first point seems to be that there have been no significant changes in coercion standards since Brown $v$. Mississippi. ${ }^{39}$ This seems simply wrong. The difference in standards for police conduct between Brown and Stroble v. California on the one hand, and Haynes $v$. Washington on the other, ${ }^{40}$ is, to say the least, quite substantial, 41 and the fact that "coerced" confessions have always been excluded seems relatively unimportant. The second point as to the importance of reliability would seem to support Professor Mishkin's position but for the fact that it is not clear from the opinion whether reliability is an indispensable element for retroactivity, or whether society's abhorrence to such a practice is an independently sufficient ground for retroactivity. ${ }^{42}$

Furthermore, Mr. Justice Clark's citation of Jackson v. Denno for the proposition that reliance is the basis for retroactivity in the confession cases seems inappropriate. Rather than dealing with the content of the voluntariness standard, Jackson dealt with the choice of persons constitutionally empowered to determine voluntariness-a quite different problem. And since Jackson affected only some seventeen jurisdictions, ${ }^{43}$ it is difficult to see how it can be used to justify retroactivity for confession cases in all jurisdictions, including those which prior to Jackson had constitutionally correct procedures for determining voluntariness. ${ }^{44}$

\section{Self-Incrimination}

The coerced confession cases indicate the inability of the reliability rationale to explain Supreme Court decisions in one area of retro-

39297 U.S. 278 (1936).

40 Compare Stroble v. California, 343 U.S. 181 (1952), and Brown v. Mississippi, 297 U.S. 278 (1936), with Haynes v. Washington, 373 U.S. 503 (1963).

11 See Developments in the Law-Confessions, 39 Harv. L. Rev. 935, 975 (1966).

42 See text accompanying notes 162-70 infra. Parenthetically, it may be noted that if society's abhorrence is a decisive and independent factor, society has as much abhorrence for the searching devices in Irvine v. California, 347 U.S. 128 (1954), the spike microphone in Silverman v. United States, 365 U.S. 505 (1961), the knock on the door at night, the brazen outrages perpetrated in Mapp, 367 U.S. at 644-45, as for the "mild whip" in the recent confession cases, like Haynes v. Washington, 373 U.S. 503 (1963), which raise the serious retroactivity problems. It is important to remember that Haynes is the relevant confession case for comparison, and not a horrifying case like Brown v. Mississippi, 297 U.S. 278 (1936), for we are concerned with the retroactivity of the recent confession cases, not of those long past.

43378 U.S. 368, 414-17 (1964).

44 In Reck v. Pate, 367 U.S. 433 (1961), where a conviction was upset because retroactive effect was given to new confession standards, the original trial was held under proper procedures, for Illinois has always followed the "orthodox" or Wigmore rule. See People v. Miller, 13 Ill. 2d 84, 96, 148 N.E.2d 455, 462 (1958); People v. Fox, 319 III. 606, 615-16, 150 N.E. 347, 351 (1926). 
activity problems; the self-incrimination cases, on the other hand, demonstrate the uncertainties and difficulties of application of the reliability approach. In addition, the facts of one self-incrimination case, Tehan v. United States ex rel. Shott, ${ }^{45}$ dramatically illustrate the artificiality of Professor Mishkin's and the Court's sharp distinction between direct and collateral attack.

In Griffin $v$. California ${ }^{46}$ the Court held that neither prosecutors nor judges could draw adverse inferences from a defendant's failure to take the stand. In reaching this conclusion, Mr. Justice Douglas' opinion noted that comment on an accused's failure to testify penalizes exercise of the fifth amendment privilege against self-incrimination, and that taking the stand will often "confuse and embarrass ... [a defendant] to such a degree as to increase rather than remove prejudices against him." 47 While recognizing that reliability "is clearly not the most generally accepted" explanation of the privilege, ${ }^{48}$ Professor Mishkin interprets the Court's language about the defendant's confusion and embarrassment as implying that improper denials or curtailments of the privilege against self-incrimination affect the reliability of the guilt-determining process. ${ }^{49}$

This January in Tehan five members of the Court seemed to accept Professor Mishkin's overall reliability rationale, but, arguing that the "privilege against self-incrimination is not an adjunct to the ascertainment of truth,"50 they denied retroactive effect to Griffin, and by implication to Malloy. This inability of Professor Mishkin and the Court to agree upon the proper outcome of an application of the reliability test is but one reflection of the test's inherent uncertainties.

As to the merits, the Court's decision seems correct with respect to the reliability implications of the privilege against self-incrimination in general, but Professor Mishkin's approach seems correct with respect to the reliability implications of comment. It seems strained to argue that the privilege against self-incrimination in general is aimed at ensuring reliability. Rather, as Professor Mishkin candidly concedes, the Court has stressed the role of the privilege in protecting the accusatorial system, a system which, by concealing information, frequently

45382 U.S. 406 (1966).

46380 U.S. 609 (1965).

47 Id. at 613, citing Wilson v. United States, 149 U.S. 60, 66 (1893).

48 Mishkin 93. For the more usual explanations, see Murphy v. Waterfront Commission, 378 U.S. 52, 55 (1964).

49 Mishkin 92.

50 Id. at 416. The Chief Justice and Mr. Justice Fortas did not participate; Justices Black and Douglas dissented on the same grounds as in their dissent in Linkletter. 
impairs the reliability of the guilt-determining process. ${ }^{51}$ Indeed, even more so than coerced confessions, evidence obtained from the mouth or files of a defendant is likely to be reliable, and though concern about coercive abuses may still be one of the values underlying the privilege, ${ }^{52}$ the privilege surely plays a very small role today in preventing such abuses.

In support of his position, Professor Mishkin points to the embarrassment and consequent prejudice which defendants may suffer when they take the stand. That this prejudice usually produces unreliable inferences of guilt is dubious, despite Mr. Justice Douglas' assertions in Griffin. Moreover, a defendant who stays off the stand faces at least as much prejudice-so much so, in fact, that probably only the fear of even greater prejudice from the exposure of a criminal record is sufficient to persuade defendants to claim the privilege. On balance, then, it seems likely that the privilege against self-incrimination reduces rather than enhances reliability. ${ }^{53}$

On the other hand, adverse comment on the exercise of the privilege not only penalizes that exercise, but also fosters the drawing of possibly erroneous inferences. Though a jury might draw such inferences in the

61 Privileges "do not in anywise aid the ascertainment of the truth, but rather they shut out the light." McCormick, The Scope of Privilege in the Law of Evidence, 16 Tex. L. REv. 447 (1938); Weinstein, supra note 5, at 228 n.23, referring to "truth-hiding" rules but agreeing with Mishkin as to retroactivity. A few common applications of the privilege may illustrate the point without belaboring it: There is no reason to think that books and records which are incriminating and therefore immune to a subpoena are less reliable than those which do not incriminate. If reliability were at all involved, we would not deny the privilege to corporations. Rogers v. United States, 340 U.S. 367, 370-71 (1951). A conviction which is precluded by an immunity statute, Counselman v. Hitchcock, 142 U.S. 547 (1892), is set aside not because guilt is at all uncertain, but because the offense is no longer punishable. A conviction based on evidence obtained either by an excessively narrow view of what is incriminatory, Malloy v. Hogan, 378 U.S. 1 (1964), or by an immunity which is limited to the laws of another jurisdiction, Murphy v. Waterfront Commission, 378 U.S. 52, 77-79 (1964), is set aside not because there was too little reliable evidence of guilt, but because the tribunal was given too much.

62 Murphy v. Waterfront Commission, 352 U.S. 52, 55 (1964); 8 WrGmore, EvidencE 317 (McNaughton rev. 1961). But see Tehan v. United States ex rel. Shott, 382 U.S. 406, 415-16 (1966).

53 Professor Meltzer cites the danger of perjury if the defendant takes the stand as one reason for allowing the privilege at trial. Meltzer, Required Records and the McCarran Act, and the Privilege Against Self-Incrimination, 18 U. CHI. L. REv. 687, 692 (1951). But the likelihood of such perjury will be considered by the jury, and the defendant's testimony discounted. On the other hand, as the text indicates, allowing the defendant to stay off the stand enables the jury to draw theoretically unwarranted inferences about the defendant's guilt. It is therefore hard to see which will breed more ultimate unreliability-the danger of such discounted perjury or the danger of improper inferences from a defendant's exercise of his privilege, which inferences probably cannot be dispelled despite instructions to the contrary. 
absence of any adverse comments, its action would not otherwise be "judicially solemnified." Indeed, the Griffin Court expressly mentioned the danger of erroneous inferences as one of the reasons for its decision. ${ }^{54}$ Thus, Professor Mishkin seems correct with respect to this facet of the privilege.

If sound, this analysis of the Griffin-Tehan problem indicates a basic shortcoming of the reliability rationale: its effect of requiring the Court to make difficult and controversial retroactivity analyses not only with respect to each individual constitutional right, but also for each facet and application of such rights. Although difficult and controversial decisions are hardly a novel experience for the Court, a theory which greatly multiplies the necessary occasions for such decisions is not one deliberately to be sought. Indeed, a desire to avoid the necessity of a multiplicity of analyses may well have been one reason why the Court in Tehan dealt with the comment privilege as a mere corollary of the privilege against self-incrimination in general, without considering the obvious special features of the comment privilege which were expressly relied upon in Griffin.

Tehan illustrates a problem with respect to another major premise of Professor Mishkin's approach: his assertion that there is a sharp difference in function between direct review and habeas corpus, an assertion which he uses to reconcile Mapp and Linkletter. ${ }^{55}$ In Tehan, as in Linkletter, the Court seemed to adopt a similar dividing line, for it held that the new rules it was announcing would be applied to cases "still pending on direct review," and thus not "final," at the time the decision was announced. Cases deemed "final" were those in which "the judgment of conviction was rendered, the availability of appeal exhausted, and the time for petition for certiorari elapsed or a petition for certiorari finally denied, all before [the relevant date of decision]. ${ }^{\prime 56}$

54 Griffin v. California, 380 U.S. 609,615 (1965). Such an inference is clearly unfair if an innocent defendant with a criminal record refrains from taking the stand for fear that his testimony as to present innocence-which will inevitably be discounted for selfinterest-will be outweighed by the evidence of his prior record.

55 See text accompanying note 11 supra.

56 Tehan v. United States ex rel. Shott, 382 U.S. 406, 461 n.3 (1966). See Linkletter v. Walker, 381 U.S. 618, 622 (1965). One possible difference between Professor Mishkin's and the Supreme Court's views is that under the latter, a new decision might apply to a habeas corpus petition if the petition had been filed before "the time for petition for certiorari elapsed." Under Professor Mishkin's view, the timing is not relevant but only whether the review sought is direct or collatexal. The Court was obviously not concerned with this distinction, and its reference in Linkletter to "still pending on direct review" cuts against this possibility.

In Johnson v. New Jersey, the Court chose not to adopt this distinction in cases governed by Escobedo v. Illinois, 378 U.S. 478 (1964) and Miranda v. Arizona, 86 Sup. Ct. 1602 (1966). See text accompanying notes 226-32 infra. 
Where federal review of the constitutionality of state criminal proceedings is concerned, the making of so sharp a distinction between review on certiorari and habeas corpus is unwarranted. There is often no significant difference with respect to age and potential staleness between the two types of cases. Rather than coming years after the conviction is final, habeas corpus is often but a routine step in the criminal defense process-the normal step taken after certiorari has been denied. ${ }^{57}$ Sometimes, it actually replaces certiorari, for in Fay v. Noia ${ }^{58}$ the Supreme Court advised criminal defendants to skip certiorari and to petition directly to the federal district court for habeas corpus. ${ }^{59}$ Even in situations in which a defendant goes through all the direct review steps, it is often nothing more than fortuitous circumstance ${ }^{60}$ which determines whether his case is still on direct review or is on collateral attack when the new decision comes down. ${ }^{61}$

The difference between review on certiorari and habeas corpus seems, even less significant when we look to function and actual operation. Although it is sometimes considered the "normal" method for obtaining federal review of state convictions, certiorari does not provide, as the Court remarked in Fay $v$. Noia, "a normal appellate channel in any sense comparable to the writ of error,"62 for the Court must limit its jurisdiction to questions that have significance beyond the immediate case. Habe's corpus, on the other hand, facilitates the Court's task in those cases it does take by providing a record focused exclusively on the federal constitutional question. ${ }^{63}$ Habeas corpus has

57 Meador, Habeas Corpus and Carta 71 (1966). Even with respect to those cases not still in litigation when the new decision comes down, the time differences are often negligible. Thus, although Linkletter was not actively pursuing his collateral remedies on June 19, 1961, and had not sought certiorari, a comparison of his case with Mapp shows how insignificant the danger of staleness becomes even where the defendant has ceased to pursue his remedies. As noted above, Linkletter's offense was actually committed at a later date than Mapp's; final review was roughly contemporaneous; and he petitioned for post-conviction relief "immediately" after Mapp was decided. 381 U.S. at 621, 641. Had relief been granted, a hearing on the illegality of the search and a possible retrial would have taken place at about the same time as any similar proceedings in Mapp.

58372 U.S. 391 (1963).

59 Id. at $437-38$.

60 These fortuities can include litigation timing, court congestion, and the Supreme Court's choice of when to announce a new rule.

61 In Commonwealth v. Negri, 419 Pa. 117, 213 A.2d 670 (1965), a capital case, defendant's time for certiorari ran out a few days before Escobedo was decided. $I d$. at 118,213 A.2d at 671 . Had the defendant filed a petition for certiorari-probably a futile gesture at that time-he would have been entitled to consideration under Escobedo. In Linkletter, the offense actually took place after Mrs. Mapp's alleged offense, with "final" review roughly contemporaneous. 381 U.S. at 641 . Here, too, the defendant decided not to file a probably useless petition for certiorari. See Tehan, a particularly difficult case, discussed in the text accompanying note 69 infra.

62372 U.S. at 436. 
thus become the primary vehicle for immediate federal review of state convictions. Further, this development has resulted in a gradual shrinking of what were once significant operational differences between review on certiorari and habeas corpus, such as the relationship to the state proceeding, ${ }^{64}$ the degree of independent fact-finding authority, ${ }^{65}$ and the significance of the defendant's violation of state procedural rules. ${ }^{66}$ From both the functional and the operational standpoints, then, it is justifiable to conclude that "the distinctions between habeas corpus proceedings and direct review are largely illusory."

In addition, drawing a line between review of certiorari and habeas corpus undercuts the Supreme Court's bypass suggestion in Fay $v$.

63 See Fay v. Noia, 372 U.S. 391, 438 (1963); Mishkin 86-87; Freund, Remarks at Sympositum on Federal Habeas Corpus, 9 UTAH L. REv. 27, 28 (1964); cf. England v. Louisiana Board of Medical Examiners, 375 U.S. 411, 416-17 (1964). For an example of an inadequately developed record, see Mishkin v. New York, 86 Sup. Ct. 958, 965-66 (1966).

64 Direct review is considered part of the original proceeding, whereas habeas corpus is independent; communication between federal and state courts is purportedly possible in the former but not in the latter. See Hart, Foreword: The Time Chart of the Justices, 73 Harv. L. Rev. 84, 120 n.106 (1959); Reitz, Federal Habeas Corpus: Impact of an Abortive State Proceeding, 74 HARv. L. REv. 1315, 1360-63 (1961). But as Fay v. Noia and other cases indicate, in many cases the habeas corpus court will "remit" the case to the state court for (a) further fact-finding, see Rogers v. Richmond, 365 U.S. 534, 547-49 (1961); Bator, supra note 2, at 514-15; (b) an application of state law which could moot the federal issue, see, e.g., United States ex rel. Johnson v. Warden, $240 \mathrm{~F}$. Supp. 486, 490:91 (S.D.N.Y. 1965); United States ex rel. Realmuto v. Fay, 230 F. Supp. 158 (S.D.N.Y. 1964); or (c) a chance to apply subsequently developed federal law, see, e.g., United States ex rel. Wynn v. Wilkins, 347 F.2d 777 (2d Cir. 1965); Miller v. Gladden, 341 F.2d 972, 975 (9th Cir. 1965); Calhoun v. Pate, 341 F.2d 885, 886 (7th Cir. 1965); Hunt v. Warden, 335 F.2d 936 (4th Cir. 1964); Delaney v. Gladden, 237 F. Supp. 1010 (D. Ore. 1965), with a right to reapply to the habeas court if relief is not granted. Thus, communication seems not much less on habeas corpus than on direct review. Moreover, the result of the two forms of review is often the same: a new trial consistent with the decision of the federal court. Hart, supra, at 120 n.106 (1959); Reitz, Federal Habeas Corpus: Post Conviction Remedy for State Prisoners, 108 U. PA. L. REV. 461, 481 n.11I (1959).

65 The habeas corpus court can take testimony and make independent findings of fact, whereas on direct review the Supreme Court supposedly cannot. But as a practical matter, the Supreme Court has done its own fact-finding in many direct review cases, see Bator, supra note 2, at 514-21; Hill, The Inadequate State Ground, 65 ColuM. L. REv. 943, 946 n.18 (1965); cf. Townsend v. Sain, 372 U.S. 293, 316 (1963), and if a full and fair state court hearing has been held under the standards of Townsend $v$. Sain, the habeas corpus court will neither review the facts too closely nor take new evidence. See Case v. Nebraska, 381 U.S. 336, 345 (Brennan, J., concurring).

66 In theory, existence of an adequate and independent state procedural ground precludes direct review but has no effect on habeas corpus. But the Court's treatment of the adequate and independent state procedural ground doctrine in Henry v. Mississippi, 379 U.S. 443 (1965), and Douglas v. Alabama, 380 U.S. 415 (1965), may well have sapped that doctrine of much of its vitality even on direct review. Hill, supra note 65, at 988-91, 993 n.205. And a vigorous application of waiver notions in habeas corpus could have the same effect as enforcement of the adequate state ground doctrine. See id. at 984.

67 Sandalow, Henry v. Mississippi and the Adequate State Ground: Proposals for a Revised Doctrine, 1965 Sup. CT. REv. 187, 234. See also Bator, supra note 2, at 517. 
Noia. If a defendant has doubts about the retroactivity of any claim which might both affect him and be subject to Court review in the foreseeable future, he will be well advised always to ignore the Court's suggestion and to apply for certiorari. Many months may pass before his petition for certiorari is rejected, and so long as it is pending, he will be entitled to receive the benefits of any intervening decisions. As soon as he files his petition for habeas corpus, however, even if he does so only a day after the last state court order is entered, he will have forfeited his right to such benefits. He will thus be put to an election between delayed relief and no relief at all. ${ }^{68}$

The inequity of drawing a sharp distinction between direct review and habeas corpus is, however, only one aspect of a broader inequity: treating two prisoners deprived of the same fundamental constitutional right differently merely because the Supreme Court did not get around to enunciating a particular right until after the conviction of one of them had become final. Professor Mishkin argues that worry about this point ignores "the reasons for barring current convictions and ... the fact that the new rule in no way undermines the earlier determinations of factual guilt." 69 To him, it is as if a guilty person were to complain of his lot because others equally guilty were not prosecuted. ${ }^{70}$

68 Both the unreality and the inequity of the sharp distinction between habeas corpus and direct review are apparent in Tehan. In that proceeding, Shott's conviction was affirmed by the Ohio Supreme Court in 1962, Shott v. State, 173 Ohio St. 542, 184 N.E.2d 213 (1962), and he immediately sought Supreme Court review on both appeal and certiorari, contending that the prosecutor's repeated comments on his failure to take the stand when there was no other evidence deprived him of a fair trial. This was almost 10 months before certiorari was granted in Griffin v. California, 380 U.S. 609 (1965). Supreme Court review was denied, 373 U.S. 240 (1963), and Shott immediately sought federal habeas corpus, raising, inter alia, the claim that the prosecutor's comment was unconstitutional. See Brief for Petitioner, p. 4, United States ex rel. Shott v. Tehan, 337 F.2d 990 (1964). While the case was pending before the Court of Appeals for the Sixth Circuit, Malloy v. Hogan, 378 U.S. I (1964), was decided. On the basis of Malloy, the Court of Appeals held the comment unconstitutional and granted the writ, six months before Griffin. United States ex rel. Shott v. Tehan, 337 F.2d 990 (1964). The State of Ohio appealed to the Supreme Court. The latter first granted certiorari after Griffin; then it reversed the Court of Appeals, holding that Tehan was not entitled to "retroactive" application of Griffin.

Can it be said, in any meaningful sense, that even though certiorari had been denied, Shott's conviction was "final" before Griffin was decided? All of these proceedings followed his original conviction in due course, without any delay. And is it not largely fortuitous that Malloy and Griffin-not Tehan-were chosen as the declaring decisions? Though logic may not provide a totally satisfying answer to retroactivity problems, see Bender, The Retroactive Effect of an Overruling Constitutional Decision: Mapp $v$. Ohio, 110 U. PA. L. REv. 650, 679 (1962), surely so fortuitous and inequitable a pattern of results as that just outlined is unacceptable where human liberty is at stake.

60 Mishkin 88.

70 The equality argument is vividly set out and illustrated in Currier, supra note 2, at 201-04, 267-68. See also CAhN, The Sense of INJustice 14-15 (1949). 
And though he recognizes that such claims are sometimes sustained, ${ }^{71}$ he concludes that "there are certainly rational bases for drawing a line between current convictions and those previously final," citing excerpts from Professors Bator and Amsterdam on finality. ${ }^{72}$ Professor Mishkin's sharp distinction between collateral attack and direct review thus rests ultimately on finality considerations.

Finality considerations seem especially weak where two cases differ only in the fact that one is still on "direct" review whereas the other is not. Where the two cases are far apart in age, finality considerations are admittedly more persuasive. But even there, the mere timing of the Court's decision to grant federal protection to a fundamental right hardly seems to be a sufficient basis for unequal treatment; after all, in most instances it was not the older prisoner's fault that the Court did not render its decision earlier. To some extent, of course, the question comes down to a choice between the competing values of equality and repose, and choices of this sort are notoriously immune to reasoned resolution. It will be suggested below, ${ }^{73}$ however, that the threat to finality considerations from complete retroactivity appears to have been greatly exaggerated, and if this suggestion is well taken, Professor Mishkin's rejection of equality is especially untenable.

\section{The Right to Counsel-Escobedo v. Illinois}

When this article was written, the retroactivity of Escobedo was pending before the Supreme Court. The Court has recently decided the issue against retroactivity, ${ }^{74}$ and a discussion of its decision appears in the Epilogue. However, the original comments may still be of value, for they raise some general issues of the administration of a reliability rationale which may recur in future cases dealing with federal and state court doctrines related to Escobedo, ${ }^{75}$ and which are

71 See generally Note, The Right to Nondiscriminatory Enforcement of State Penal Laws, 61 CoLuM. L. REv. 1103 (1961).

72 Mishkin 88 \& n.116.

73 See text accompanying notes $122-47$ infra.

74 Johnson v. New Jersey, 86 Sup. Ct. 1772 (1966). For a pre-Johnson discussion of this problem in general agreement with the conclusions reached herein, see Note, Linkletter, Shott, and the Retroactivity Problem in Escobedo, 64 MrcH. L. REv. 832 (1966).

75 People v. Rivera, 16 N.Y.2d 879, 211 N.E.2d 649, 264 N.Y.S.2d 249 (1965) (People v. Donovan, 13 N.Y.2d 148, 193 N.E.2d 628, 243 N.Y.S.2d 841 (1963), held not retroactive). It should also be noted that Johnson left the states free to give Escobedo (and Miranda) greater retroactive effect, and the considerations set forth in this section may thus be pertinent. The likelihood of such action by the states is small, however, for prior to Johnson, few cases had given Escobedo retroactive effect. Compare United States ex rel. Walden v. Pate, 350 F.2d 240 (7th Cir. 1965), In re Lopez, 62 Cal. 2d 368, 398 P.2d 380, 42 Cal. Rptr. 188 (1965), and Commonwealth v. Negri, 419 Pa. 117, 213 A.2d 670 (1964), with United States ex rel. Russo v. New Jersey, 35I F.2d 429 (3d Cir. 1965) (see particularly Forman, 
still open. Moreover, since they reach a different result from Johnson, the original comments may serve as a partial criticism of that decision.

The problem was complicated by the uncertainties of the scope and purpose of Escobedo. Possible readings of the case ranged from the one extreme of a mere requirement that the defendant be notified of his rights, to the other of a requirement that a court-appointed lawyer be present from the moment of arrest, if not earlier. These possibilities have been canvassed elsewhere at great length, ${ }^{76}$ and, as will be shown in the Epilogue, still have not been resolved. ${ }^{77}$ Because of these uncertainties, a full analysis of the retroactivity aspects of the case on the basis of a theory which, like Professor Mishkin's, makes retroactivity dependent on the "intended effects" of the decision involved, seemed and still seems somewhat premature.

A further and related complicating factor was the presence of several potentially applicable but conflicting lines of precedent. Insofar as Escobedo is a right to counsel case, Gideon points toward retroactivity; insofar as it is a self-incrimination case, Tehan points toward prospectivity; and insofar as it is a coerced confession case, Reck v. Pate ${ }^{78}$ may imply retroactivity. This article focuses on implications only of the coerced confession and right to counsel aspects of the decision.

Though Professor Mishkin believes that coerced confession cases should be applied retroactively, he concludes that Escobedo should not be. He states his position thus:

Mr. Justice Goldberg's opinion for the Court [in Escobedo] formally rests the decision upon the right to effective assistance of counsel. However, the discussion also brings to bear the policies underlying the privilege against self-incrimination as well as the considerations supporting the rule against involuntary confessions. Though these latter doctrines may be regarded as indirectly relevant, indicating some of the ways in which assistance of counsel may help preserve an individual's other constitutional rights, it is possible that they have independent significance in the holding as well. But regardless

C.J., concurring at 442-43), vacated, 34 U.S.L. WEEK 3425 (June 20, 1966), United States ex rel. Walker v. Fogliani, 343 F.2d 43, 47 (9th Cir. 1965), and Miller v. Warden, 338 F.2d 201 (4th Cir. 1964).

76 E.g., Herman, supra note 28; Kamisar, Equal Justice in the Gatehouses and Mansions of American Criminal Procedure, in KAMISAR, INBAu \& ARNOLD, GrMminal Justice IN OUR TIME (1965) [hereinafter cited as Kamisar, Equal Justice]; Developments in the Law-Confessions, 79 HARv. L. REv. 935, 996-1023 (1966); Enker \& Elsen, Counsel for the Suspect: Massiah $v$. United States and Escobedo 7 . Illinois, 49 MrN. L. REv. 47 (1964).

77 See text accompanying notes 241-43 infra.

78367 U.S. 433 (1961). 
of the precise relevance of these doctrines to the holding, it is clear that the constitutional objectives of Escobedo lie primarily in the direction of protecting human integrity and dignity rather than of increasing the reliability of the processes for determining guilt. It should be remembered, in this connection, that any confession to the police was already subject to exclusion if found to be involuntary under previous authority, itself quite far-reaching in its protections. Escobedo's added reach thus does not seem principally aimed at improving the trustworthiness of suspects' statements; protection of personal dignity and integrity, within the framework of an adversary system, seems a far more satisfactory rationale. ${ }^{70}$

It is difficult to understand how Professor Mishkin can so quickly dismiss the coerced confession and privilege aspects of Escobedo. As to the first, the only one to be discussed here, one of the most common explanations of Escobedo-an explanation relied upon by both proponents and opponents of retroactivity ${ }^{80}$ - was that the decision was designed primarily to eliminate the possibility of coerced confessions by preventing the creation of coercive environments. A related common explanation was that the case was a reaction to the Court's inability to penetrate the interrogation room to determine whether the confessions before it were indeed voluntary. ${ }^{81}$ Thus, at least part of Escobedo's protection of "personal dignity and integrity" during the interrogation process was seen as being aimed at the prevention of coercion..$^{82}$ The recognition of such an aim implies a view that situations which do not comply with Escobedo's requirements are likely to be coercive, and that the absence of impartial witnesses from such situations not

79 Mishkin 95.

80 Compare In re Lopez, 62 Cal. 2d 368, 376-78, 398 P.2d 380, 386-88, 42 Cal. Rptr. 188, 194-96 (1965), and United States ex rel. Walden v. Pate, 350 F.2d 240, 242 (7th Cir. 1965), with United States ex rel. Russo v. New Jersey, 351 F.2d 429, 442-43 (3d Cir. 1965) (Forman, C.J., concurring), vacated, 34 U.S.L. WeEK 3425 (June 20, 1966).

81 See, e.g., United States ex rel. Russo v. New Jersey, 351 F.2d 429, 443 (3d Cir. 1965) (Foreman, C.J., concurring), vacated, 34 U.S.L. WrEK 3425 (June 20, 1966); In re Lopez, 62 Cal. 2d 368, 374-75, 398 P.2d 380, 384-85, 42 Cal. Rptr. 188, 192-93 (1965); Developments in the Law-Confessions, 79 HaRv. L. REv. 935, 963 (1966). Professors Mishkin and Amsterdam in their brief for the American Civil Liberties Union in Miranda stressed the link between Escobedo and coercion, stating that: "The step from Haynes to Escobedo is an extremely short one, if, indeed, one at all. If Haynes represents the capstone of the "involuntary' confession cases, then Escobedo represents the application of this capstone in light of the full Fifth Amendment protection held to be applicable to State interrogation by Malloy." Brief for A.C.L.U. as Intervenor, p. 21. Professor Mishkin has written me that this brief represents what he takes Escobedo to mean. In Miranda, the Court adopted the basic approach and many of the details of the A.C.L.U. brief.

82 Cf. Enker \& Elsen, supra note 76, at 66-67. 
only increases the likelihood of coercion, ${ }^{83}$ but also ensures that the courts cannot know whether coercion took place. Analogy to Gideon has suggested the question:

Would it be too strained to argue that just as the great difficulty of proving what legal defenses a lawyer might have made and what facts he might have marshalled casts a shadow over the conviction of every uncounselled defendant, so the great difficulty of proving what the police did or threatened or promised in the secret interrogation proceedings raises doubts about the reliability of every confession obtained from a suspect denied counsel? ${ }^{84}$

On the other hand, the institution of an additional protection against coerced confessions does not logically require the conclusion that all or even most confessions taken without this protection are likely to be coerced. And it does seem somewhat strained to argue that the reliability of confessions taken without a lawyer is as suspect as the reliability of trials conducted without a lawyer. But reliability is not the only or even the main purpose of the coerced confession rule. ${ }^{85}$ Other values subsumed under the term "voluntariness" include the deterrence of improper police pressure and the prevention of ignorant, duped, or compelled waivers of the privilege against selfincrimination. The likelihood of violating these values in the interrogation process is far from negligible ${ }^{86}$ - in fact, it is probably greater than the likelihood of obtaining unreliable confessions. ${ }^{87}$ And whatever the values sought to be protected by the rule against coerced confessions, the Supreme Court must have thought they were receiving extremely inadequate protection prior to Escobedo, for Escobedo is, as the Court itself recognized, ${ }^{88}$ rather strong medicine. Since a remedy so drastic seems appropriate only for a very serious

83 See Inbau \& Reid, Criminal Interrogation and Confessions 1 (1962), stating that privacy is indispensable to effective interrogation.

84 Hall \& Kamisar, Basic Criminal Procedure 293-94 (1965) (emphasis in original).

85 See text accompanying notes $26-43$ supra.

86 INBAU \& REID, supra note 83, at $1-139$, describes a full array of the interrogational techniques and pressures that facilitate the violation of these values. See also O'HARA, Fundamentals of Criminal Interrogation, ch. 9 (1956). Both of these manuals were quoted extensively and critically by the Court in Miranda. 86 Sup. Ct. at 1614-17.

87 But see authorities cited notes 29 \& 34 supra for the possibility of partial inaccuracy.

88 See 378 U.S. at $488-90$, recognizing that the number of confessions obtained might be fewer under the decision. The Court could probably have decided the case in the same way on a traditional "voluntariness" rationale, on the facts of the case. See Herman, supra note 28 , at $472-73$. A decision on voluntariness grounds would have had a much lighter impact. 
problem, the Court must have thought that the likelihood of improper pressure in secret interrogations was considerable. Thus, if Professor Mishkin's comment that "pre-Escobedo authority already provided for the exclusion of the vast bulk of confessions having substantial likelihood of being untrustworthy in fact" 89 is meant to be interpreted as saying that pre-Escobedo authority successfully excluded "the vast bulk of confessions having any substantial likelihood" of having been obtained in violation of the other values subsumed under the term "voluntariness," it is clearly a minority view.

Though coerced confession cases loomed large in the background, Escobedo was actually decided under the sixth amendment as a case involving the right to counsel at the early stages of the criminal process. The Court had already decided that the right to counsel at a later stage of that process is to be given retroactive effect, ${ }^{90}$ and Professor Mishkin approves of this decision. Thus, his rejection of retroactivity for Escobedo implies a belief that different stages of the criminal process have different right-to-counsel retroactivity aspects, depending, apparently, on the significance of counsel's presence to the guilt-determining and fact-finding functions of the different stages. Surely, this further multiplication of problems ${ }^{91}$-problems so difficult that Professor Mishkin devotes more than one-seventh of his article to Escobedo alone-does not further the goals set forth by him in his Part $I$ and makes his test all the more difficult to apply.

Moreover, is Escobedo so different from Gideon and the other rightto-counsel cases? Although the discussion to this point has focused on Escobedo's importance to coercion and self-incrimination, the opinion's structure and precedents support a broader role for the right to counsel. The opinion can be broken down into two parts. The first sets out an affirmative statement of precedents and policy, ${ }^{92}$ while the second replies to arguments that the presence of counsel has unduly harmful effects on interrogation..$^{93}$ In its first part, the opinion relies

89 Mishkin 96-97.

90 Gideon v. Wainwright, 372 U.S. 335 (1963); Picklesimer v. Wainwright, 375 U.S. 2 (1963) (per curiam).

91 For example, is Massiah v. United States, 377 U.S. 201 (1964), closer to Gideon than to Escobedo? What of Hamilton v. Alabama, 368 U.S. 52 (1961), or White v. Maryland, 373 U.S. 59 (1963)? A recent commentator speculates that all of these will be granted full retroactivity. Note, Linkletter, Shott, and the Retroactivity Problem in Escobedo, 64 Mrch. L. Rev. 832, 843 (1966). See also McWilliams v. Gladden, 407 P.2d 833, 840 (Ore. 1965) (dissenting opinion). But see United States ex rel. Romano v. Fay, 360 F.2d 389 (2d Cir. 1966) (Massiah held not retroactive).

92378 U.S. at $484-88$.

$93 \mathrm{Id}$. at $488-92$. 
almost exclusively on sixth amendment authorities: Massiah, ${ }^{94}$ the concurrence in Spano, ${ }^{95}$ Powell, ${ }^{96}$ Hamilton, ${ }^{97}$ White, ${ }^{98}$ the New York decision in Donovan, ${ }^{99}$ and Gideon. ${ }^{100}$ One implication of this reliance is a view that Escobedo extends a full right to counsel to the accusatory stage of the criminal process. This right is designed not only to prevent coerced confessions and protect the privilege against selfincrimination, but also to ensure the giving of any and all other services that a lawyer might be able to offer at such a "critical stage."101 These might include explaining to the defendant the significance of what is happening so that he knows exactly what he faces, bargaining for the defendant with the police, ${ }^{102}$ assisting the defendant in making exculpatory statements, ${ }^{103}$ preventing against unfair lineups, ${ }^{104}$ guarding against errors or overreaching in transcription, ${ }^{105}$ and perhaps even advising a plea or a confession. ${ }^{106}$ In short, a lawyer can perform at the accusatory stage whatever services lawyers are normally called

94 Massiah v. United States, 377 U.S. 201 (1964).

95 Spano v. New York, 360 U.S. 315, 326 (1959) (Stewart, J., concurring).

96 Powell v. Alabama, 287 U.S. 45 (1932).

97 Hamilton v. Alabama, 368 U.S. 52 (1961).

98 White v. Maryland, 373 U.S. 59 (1963) (per curiam).

99 People v. Donovan, 13 N.Y.2d 148, 193 N.E.2d 628, 243 N.Y.S.2d 841 (1963).

100 Gideon v. Wainwright, 372 U.S. 335 (1963).

101 Enker \& Elsen, supra note 76, at 69; Comment, The Curious Confusion Surrounding Escobedo v. Illinois, 32 U. CHI. L. Rev. 560 (1965). The New York cases, in relying explicitly on both the right to counsel and the privilege against self-incrimination, People v. Donovan, 13 N.Y.2d 148, 193 N.E.2d 628, 243 N.Y.S.2d 841 (1963), have indicated that other services were also involved: "[O]ne of the most important protections which counsel can confer while his client is being detained ... is to ... prevent the deprivation of [the privilege against self-incrimination] and other rights which may ensue from such detention." Id. at 151-52, 193 N.E.2d at 629, 243 N.Y.S.2d at 843 (emphasis added).

102 Kamisar, Equal Justice 37-38. This is more likely to take place in the District Attorney's office.

103 See Ferguson v. Georgia, 365 U.S. 570, 594 (1961); Kamisar, Equal Justice 16. The lawyer may be particularly necessary in helping to explain noncriminal but nevertheless suspicious conduct. It would be better to do this in the police station rather than in the District Attorney's office, contrary to the plea situation, in order to prevent the making of a formal arrest.

104 Cf. Wade v. United States, 358 F.2d 557 (5th Cir. 1966) (eyewitness saw defendant alone in custody of police before identifying him in lineup); United States ex rel. Stovall v. Denno, 355 F.2d 731, 744 (2d Cir. 1966) (Friendly, J., dissenting), cert. granted, 34 U.S.L. WeEK 3429 (June 20, 1966). Both cases involve post-indictment lineups. See also Palmer v. Peyton, 359 F.2d 199 (4th Cir. 1966); People v. Gilbert, 408 P.2d 365, 47 Cal. Rptr. 909, 920-21 (1965), cert. granted, 34 U.S.L. WEEK 3418 (June 14, 1966).

105 See authorities cited notes 29 \& 34 supra for the danger of partial inaccuracy.

106 See the comments of Mr. Justice Fortas on oral argument of Miranda v. Arizona, 34 U.S.L. WeFk 3299 (March 8, 1966); Kamisar, Equal Justice 37; Note, An Historical Argument for the Right to Counsel at Interrogation, 73 YALE L.J. 1000, 1049 (1964). Advising a plea may also be unlikely at so early a stage. 
on to perform, not the least of which is simply to be there at a critical moment, even if relatively passive. ${ }^{107}$

The absence of some of these legal services, such as guidance in making a statement, assistance with exculpatory statements, and prevention of unfair lineups, can affect reliability. Professor Mishkin recognizes some reliability implications of the presence of counsel, ${ }^{108}$ but because he does not envisage so broad a role for counsel, he does not consider reliability to be overly significant in Escobedo. If the notion of a broad role for counsel in the accusatory stage is accepted, however, retroactivity would seem as appropriate for Escobedo as for Gideon, even under a reliability rationale.

\section{Summary}

These varied and numerous uncertainties point up a basic shortcoming of Professor Mishkin's thesis that constitutional rights should be given retroactive application only when one of their "intended effects" serves to further reliability. Constitutional rights often further a variety of purposes, ${ }^{109}$ and a specific situation or problem may raise a variety of constitutional rights. ${ }^{110}$ The strands of doctrine and policy in constitutional due process rights are often numerous, tangled, and uncertain in scope, and the significance of any particular strand is often hard to assess. ${ }^{111}$ Yet, Professor Mishkin's approach expressly requires that this extremely difficult task be undertaken with respect to every distinct facet and application of every right, often soon after the right has been declared and before uncertainties have been re-

107 This broader notion of the right to counsel is really not altogether novel. It goes back to Powell v. Alabama, 287 U.S. 45 (1932), which referred to the need for the guidance of counsel at every critical stage of the proceedings, without indicating any limitation of counsel's function. See Kamisar, Equal Justice 56. On the other hand, many lawyers will simply tell their clients to keep silent, and nothing more will be involved. 108 Mishkin 96-99.

109 Consider the range of possible contexts in which the privilege against self-incrimination and the right to counsel may apply.

110 Thus, police station interrogation raises self-incrimination, right to counsel and due process voluntariness considerations; for the possible constitutional issues raised by entrapment, see Note, The Serpent Beguiled $M e$ and I Did Eat: The Constitutional Status of the Entrapment Defense, 74 YALE L.J. 942 (1965).

111 Mapp v. Ohio, 367 U.S. 643 (1961), is a particularly good example of this. See also Kamisar, Equal Justice 6-9, on the ramifications of Griffin v. Illinois, 351 U.S. 12 (1956), and Douglas v. California, 372 U.S. 353 (1963). The difficulty of weighing the importance of any particular element in the decision is one reason why that decision cannot be made immediately, as has been suggested. Friendly, The Bill of Rights as a Code of Criminal Procedure, 53 CaLIF. L. REv. 929, 940 n.64 (1965), Delay is necessary under any theory which allows retroactivity only to those decisions based on a particular rationale, for it may not be possible to determine whether a new decision falls within that rationale until the ramifications of the new decision are clarified. 
duced. The difficulties and perplexities set forth above will thus be encountered again and again.

Moreover, the courts will face problems in dealing with rights which do not fit easily into the Mishkin dichotomy. Professor Mishkin discusses only procedural due process and not equal protection, and thus a separate analysis may be needed for the latter area.112 And what of such rights as cruel and unusual punishment and double jeopardy?113 Neither of these rights affects in any significant sense the reliability of the guilt-determining process, but surely we do not want to acquiesce in the continued imposition of a penalty we now consider too cruel or the continued punishment of a person tried twice for the same offense. To cover these and similar rights, then, we will need different analyses. ${ }^{114}$

Nor can such distinctions and refinements be limited to the interjurisdictional retroactivity context. Professor Mishkin's analysis is explicitly based not on considerations peculiar to retroactivity in a changing law context, but rather on the function of habeas corpus in assuring procedural due process in all contexts. Thus, it would seem to include intrajurisdictional cases even where old standards are involved. On his view of the function of habeas corpus, Professor Mishkin would always deny relief to intrajurisdictional cases not involving rights affecting reliability, for the alternate purpose of habeas corpus - supervising state application of federal law-would not be relevant.115 Yet, habeas corpus relief has been granted to federal prisoners raising claims not involving the reliability of the fact-finding process, such as search and seizure, ${ }^{116}$ double jeopardy, ${ }^{117}$ substantive uncon-

112 See Coppedge v. United States, 369 U.S. 438, 447 n.13 (1962); cf. Bolling v. Sharpe, 347 U.S. 497,499 (1954).

113 The Court has just granted certiorari in a case raising the question of whether the fourteenth amendment incorporates the double jeopardy provision of the fifth. Cichos v. Indiana, 86 Sup. Ct. 1270 (1966). See United States ex rel. Hetenyi v. Wilkins, 348 F.2d 844 (2d Cir. 1965). The cruel and unusual punishment clause is already absorbed. Robinson v. California, 370 U.S. 660 (1962); Louisiana ex rel. Francis v. Resweber, 329 U.S. 459 (1947) (dictum).

114 Indeed, in light of Professor Mishkin's overriding concern for the reliability aspects of due process, can he justifiably limit habeas corpus to constitutional errors affecting reliability? Why not all such errors, including improperly admitted or excluded evidence, newly discovered evidence, and errors respecting the scope of cross-examination?

116 See, e.g., Mishkin 77 n.71, 89 n.118.

116 The availability of post-conviction relief for search and seizure claims is still disputed. See Amsterdam, Search, Seizure and Section 2255: A Comment, 112 U. PA. L. REv. 378 (1964).

117 Nielsen, Petitioner, 131 U.S. 176 (1889) (indictment for offense already punished); Ex parte Lange, 85 U.S. (18 Wall.) 163 (1873) (multiple punishment). 
stitutionality on the face of the statute, ${ }^{118}$ and defects in the indictment, ${ }^{119}$ and the Supreme Court has given no indication that habeas corpus relief is narrower in scope for federal prisoners than for state prisoners. Indeed, the Court in Sunal v. Large and Fay v. Noia intimated that habeas corpus relief might be broader for federal prisoners. ${ }^{120}$ The present scope of habeas corpus relief is far from clear, and adoption of the Mishkin approach, which would require a multiplicity of rationales and distinctions, would make this "untidy area of the law"121 even more untidy.

To sum up, Professor Mishkin's approach is difficult to apply but requires frequent application; rests on artificially sharp and often inequitable distinctions between collateral attack and direct review; and is too limited in scope to offer adequate explanations of certain areas of constitutional criminal procedure. An approach containing so many defects requires many offsetting benefits indeed.

\section{Finality}

The benefits Professor Mishkin finds in his approach all relate to the attainment of finality. Consequently, analysis is required of the force and weight of considerations of finality.

A vigorous argument for finality has been made by Professors Paul Bator and Anthony Amsterdam, both of whom are quoted approvingly and extensively by Professor Mishkin.122 In explaining "why ... [we] seek a point at which . . . a judgment becomes final," Professor Bator mentions:

[1] Conservation of ... all of the intellectual, moral and political resources involved in the legal system ....

[2] [There is] nothing more subversive of a judge's sense of responsibility ... than an indiscriminate acceptance of the notion that all shots will always be called by someone else ....

[3] [I]t is essential to the education and deterrent functions

118 Ex parte Siebold, 100 U.S. 371 (1879). Compare Amsterdam, Search, Seizure and Section 2255: A Comment, 112 U. PA. L. REv. 378, 384 n.30 (1964), with Bator, Finality in Criminal Law and Federal Habeas Corpus for State Prisoners, 76 HARv. L. REv. 44I, 474 (1963).

119 Ex parte Bain, 121 U.S. I (1887).

For listings of cases in which habeas corpus relief has been granted to federal prisoners, see Fay v. Noia, 372 U.S. 391, 414, 409 n.17, 410 nn.20-21 (1963); Student Symposium, Post-Conviction Remedies-The Federal Approach: Constitutional Grounds for Relief, 27 OHIо Sr. L.J. 321 (1966); Note, The Writ of Habeas Corpus in the Federal Courts, 35 Colum. L. REv. 404 (1935). See also Sunal v. Large, 332 U.S. 174, 185-87 (1947) (Frankfurter, $J$., dissenting).

120 Fay v. Noia, 372 U.S. 391, 412 (1963); Sunal v. Large, 332 U.S. 174, 179-80 (1947).

121 Sunal v. Large, 332 U.S. 174, 184 (1947) (Frankfurter, J., dissenting).

122 Mishkin 77 n.71, 80 n.80. 
of the criminal law that we be able to say that one violating that law will swiftly and certainly be subject to punishment, just punishment . . . .

[4] Repose is a psychological necessity in a secure and active society ... [although this is] not [to] counsel a smug acceptance of injustice merely because it is disturbing to worry about whether injustice has been done. ${ }^{123}$

He then suggests certain limitations on finality to ensure the preservation of fairness and jurisdictional competence in the corrective process. $^{124}$

Professor Bator's four considerations are all obviously important, but his estimate of the damage that easily available federal habeas corpus would cause to them seems exaggerated. First, there is little indication so far that our "intellectual, moral and political resources" have been strained by the increased number of state habeas corpus petitions. ${ }^{125}$ Since most petitions are denied out of hand without even a hearing, ${ }^{126}$ and since hearings, when held, are usually brief, there would seem to be little real strain on our physical resources. As to the other kinds of resources, it is difficult to pin down the existence of any such strain. Indeed, it could be argued that continued and frequent consideration of constitutional claims will strengthen our moral and

123 Bator, supra note 117 , at $451-53$.

124 Id. at 453-62.

125 See Gellhorn, Remarks at Symposium on Habeas Corpus, 9 UTAH L. REv. 31, 32-33 (1964).

126 In the fiscal year ending June $30,1965,468$ hearings were held in 88 federal district courts on state habeas corpus proceedings. This constituted $11 \%$ of the total petitions filed. Letter from J. F. Spaniol, Jr., Administrative Office of the U.S. Courts, to the author, April 27, 1966. While this averages out to 5 or 6 per year for the 88 districts, some districts have much more. Thus, between July 1964 and November 1965, 200 habeas corpus petitions were filed and 52 hearings held in the Western District of New York, the location of Attica State Prison, a maximum security prison. The two judges in this district averaged about 20 hearings per year; a third judge will soon be added, reducing each judge's load by a:third. In fiscal 1965, in eight of the twelve districts listed by Justice Walter V. Schaefer as handling two-thirds of all petitions, Schaefer, Federalism and State Criminal Procedure, 70 HARv. L. REv. 1, 21 n.79 (1956), 40 judges held approximately 188 hearings in 1159 cases. Letters to the author from clerks of the Northern District of California, Eastern District of Pennsylvania, Eastern District of Illinois, Northern District of Illinois, Northern District of New York, District Court of Kansas, Northern District of Indiana, and Eastern District of Washington. In other jurisdictions, the burden is lighter. See Caffrey, The Impact of the Townsend and Noia Cases on Federal District Judges, 33 F.R.D. 446 (1963). In many instances, the number can be further reduced by imaginative handling. See Sanders v. United States, 373 U.S. 1, 122-23 (1963); Pope, Suggestions for Lessening the Burden of Frivolous Applications, 33 F.R.D. 409 (1962). Most hearings are apparently quite short. Gellhorn, supra note 125, at 32-33; Reitz, Federal Habeas Corpus: Postconviction Remedy for State Prisoners, 108 U. PA. L. REv. 461,478 (1960). See also Note, The Burden of Federal Habeas Corpus for State Prisoners, 52 VA. L. REv. 486, $491-97$ (1966), for a recent statistical study to the same effect. 
intellectual resources. After all, the Supreme Court's recent expansion of individual rights has certainly made not only the courts, but also the bar and lay public, more sensitive to due process considerations.

Second, no one has ever called for indiscriminate acceptance of the notion that all the shots will always be called by someone else. Federal habeas corpus for state prisoners is limited to constitutional issues, and since the shots are called under the standards of Townsend $v$. Sain, ${ }^{127}$ state court rulings based on full and fair evidentiary hearings are routinely affirmed. ${ }^{128}$ On the other hand, the possibility of some second guessing has certainly produced an increased sensitivity to constitutional rights on the part of state courts. ${ }^{129}$

Third, we currently know too little about and do too little for prisoner education and deterrence to warrant firm judgments that liberal habeas corpus impairs those objectives. ${ }^{130}$ It seems especially unlikely that the federal post-conviction remedy operates as a significant factor in view of the far greater number of state post-conviction petitions filed by most long term prisoners.

Finally, repose seems something less than "a psychological necessity," for so long as a person is kept in prison, the matter is final neither for him nor for the society that keeps-and supports-him there. ${ }^{131}$

127372 U.S. 293 (1963). This case was decided after Professor Bator's article was published.

128 Id. at 312-18; see Case v. Nebraska, 381 U.S. 336, 345 (1965) (Brennan, J., concurring). The need to exhaust state remedies also minimizes federal intervention. A cursory survey of the advance sheets indicates that the federal courts have tried to ensure that state courts have an opportunity to decide the questions that are raised. See, e.g., United States ex rel. Dalton v. Myers, 342 F.2d 203 (3d Cir. 1965); United States ex rel. Walker v. Fogliani, 343 F.2d 43 (9th Cir. 1965); United States ex rel. Calhoun v. Pate, 341 F.2d 885 (7th Gir. 1965).

Professor Gellhorn has also noted how rarely state court convictions are set aside, but his figures relevant to 1959 may be a bit obsolete. See Gellhorn, supra note 125, at 33. See also Reitz, supra note 126, at 486-87.

129 See Case v. Nebraska, 381 U.S. 336 (1965); Schaefer, supra note 126, at 16-17; cf. Reitz, supra note 126, at 469, 487.

130 See Sykes, The SocietY of Gaptives 10-12 (Atheneum ed. 1965); Bennett, Our Penal System: Does it Deter Violence?, 4 AM. Crum. L.Q. 68 (1966). Professor Paul Freund has commented that filing habeas corpus petitions may actually have a positive therapeutic and educational effect on prisoners. Moreover, much of our crime is committed by the underprivileged and disadvantaged, those who find society cruel, unfair, and hypocritical. The concern for equal justice reflected in a system which does not forget such people but continues to attempt to rectify any injustice they may have suffered can also have a significantly deterrent and educational effect. On the other hand, rehabilitation is seriously hindered if a prisoner feels he has been the victim of inequitable treatment. See Newman, Conviction 43 (1966).

131 Gf. United States ex rel. Angelet v. Fay, 333 F.2d 12, 25 (2d Cir. 1964) (Marshall, J., dissenting), aff'd, 381 U.S. 654 (1965); Meador, Habeas Corpus and the "Retroactivity" Illusion, 50 VA. L. REv, 1115, 1117 (1964). Though this can be said for the accused in 
Professor Amsterdam stresses the administrative inconvenience and impaired reliability of a hearing or new trial many years after the event. ${ }^{132}$ At first blush, considerations of impaired reliability seem important, but if one considers the fallibility of both the fact-finding and judgmental criminal processes, ${ }^{133}$ and takes into account the waste of valuable human resources implicit in any penal system, the balance of social utility and overall reliability is far from clear.

Supporting, and perhaps underlying, the above finality considerations is a further concern: the fear of a legalized mass jail break by rapists, murderers, and other felons. ${ }^{134}$ This fear is reflected in the concern expressed in Tehan about the possibility of unsuccessful retrials of all defendants who did not take the stand in six states, ${ }^{135}$ and in Mr. Justice Glark's comment in Linkletter that prior police lawlessness would not be deterred "by the wholesale release of the guilty victims." 138

The concern expressed in Tehan seems well-founded, ${ }^{137}$ though a harmless error rule, which the Court is apparently considering for

every adverse judgment of continuing significance, the fundamental difference between continuing imprisonment and other continuing effects needs no elaboration. This, of course, is one reason why res judicata does not apply to habeas corpus. Sanders v. United States, 373 U.S. 1 (1963). See also id. at 8: "Conventional notions of finality of litigation have no place when life or liberty is at stake and infringement of constitutional rights are alleged."

132 Amsterdam, Search, Seizure and Section 2255: A Comment, 112 U. PA. L. REv. 378, 383-84 (1964) (quoted at Mishkin 77 n.71):

The ... characteristics of collateral litigation [which] may be denominated aspects of a "finality" factor ... involve (a) duplication of judicial effort; (b) delay in setting the criminal proceeding at rest; (c) inconvenience and possibly danger in -transporting a prisoner to the sentencing court for hearing; (d) postponed litigation of fact, hence litigation which will often be less reliable in producing the facts (i) respecting the post-conviction claim itself, and (ii) respecting the issue of guilt if the collateral attack succeeds in a form which allows retrial (the burden of proof of guilt on retrial, of course, remaining with the prosecutor). In combination, these finality considerations amount to a more or less persuasive argument against the cognizability of any particular collateral claim, the strength of the argument depending upon the nature of the claim, the manner of its treatment (if any) in the conviction proceedings, and the circumstances under which collateral litigation must be had.

133 For a survey of the system's fallibility, see Weinstein, Some Difficulties in Devising Rules for Determining Truth in Judicial Trials, 66 CoLvM. L. REv. 223, 229-41 (1966). The fallibility extends not only to the question of guilt of some crime, but also to the particular crime committed, and to the basis for and length of the sentence, all of which are significant in determining the legality of the detention at the time habeas corpus relief is requested.

134 See, e.g., In re Lopez, 62 Cal. 2d 368, 381, 398 P.2d 380, 390, 42 Cal. Rptr. 188, 198 (1965); Commonwealth v. Negri, 419 Pa. 117, 128, 213 A.2d 670, 676 (1965) (concurring opinion); Brief for the State of New York and Other States as Amicus Curiae, pp. 45-46, Miranda v. Arizona, 86 Sup. Ct. 1602 (1966).

135382 U.S. at $418-19$ (1966).

136381 U.S. at 637 (1965).

137 But see Mishkin 94 n.142. 
Griffin, ${ }^{138}$ might minimize problems. But insofar as the comment rule is concerned, the possibility of a legalized mass jail break would seem to be simply part of the price we must now pay for former failures to provide fair procedures, for here if anywhere the effect on the reliability of the guilt-determining process is clear. On the other hand, it seems unlikely that many prisoners would be released by the retroactive allowance of claims of illegal search and seizure.139 For one thing, since a good proportion of search and seizure cases involve minor narcotics or gambling offenses, many of the victims of illegal searches are likely to be out of prison now that five full years have passed since $M a p p .{ }^{140}$ For another, cases in which a guilty plea was entered are generally immune from collateral attack. ${ }^{141}$

Doubts have also been expressed that many prisoners would be released by a retroactive application of Escobedo. ${ }^{142}$ Though uncertainties about the reach of Escobedo make assured judgment as difficult here as elsewhere, some of the factors previously discussed with respect to search and seizure would seem equally relevant here. ${ }^{143}$ Moreover, it is now clear that far fewer convictions result solely from confessions than was formerly thought ${ }^{144}$ and that retrials may be successful in many cases.

138 See Chapman v. California, 86 Sup. Ct. 1228 (1966) (whether harmless error rule should apply to Griffin). Compare State v. Johnson, 43 N.J. 572, 590-91, 206 A.2d 737, 747 (1965), aff'd on other grounds, sub nom. Johnson v. New Jersey, 86 Sup. Ct. 1772 (1966). For problems with one harmless error rule, see Hall \& KaMISAR, ModERN Criminal Procendre 299-300 (1965).

139 See Sober, Current Problems in the Law of Searcer and Seizure 124 (1964). But see Brief for the State of New York, supra note 134, at 46 n.1; Allen, Federalism and the Fourth Amendment: A Requiem for Wolf, 1961 Sup. CT. REv. 1, 43 n.204.

140 The median length of detention for prisoners released from New York State's maximum security prisons was less than 33 months; the median length for all New York State prisoners was only 24.7 months. Only 472 of 3701 prisoners released from the New York State maximum security prisons in 1964 had been in for five years or longer; for all New York State prisoners, the figures are 515 of 4052. Letter from New York State Department of Correction to the author, May 19, 1966. The national median of time served for all felony offenders in state prisons in 1960 was 16.7 months, with only $8.7 \%$ serving five or more years. Federal Bureau of Prisons, National Prisoner StatisticsCharacteristics of State Prisoners: 1960, 26-27 (1965).

141 E.g., Watts v. United States, 278 F.2d 247 (D.C. Cir. 1960).

142 See Commonwealth v. Negri, 419 Pa. 117, 126, 213 A.2d 670, 679-80 (1965) (Roberts, J., dissenting); Note, Linkletter, Shott, and the Retroactivity Problem in Escobedo, 64 Mrch. L. REv. 832, 849-54 (1966).

143 See text accompanying notes $140-41$ supra.

144 See Remarks of Judge Sobel, Symposium-Should Confessions Be Abolished?, 2 Crim. L. Bull., March 1966, pp. 13-16; Kamisar, Has the Court Left the Attorney General Behind? (pt. 2), 155 N.Y.L.J., Feb. 24, 1966 p. 4 n.29; cf. Ritz, State Criminal Cases: Subsequent Developments in Cases Reversed by the United States Supreme Court and Some Current Problems, 19 WASH. \& LEE L. REv. 202 (1962). But see Note, Developments in the Law-Confessions, 79 HaRv. L. Rev. 935, 942-43 (1966) (criticizing the implications drawn by Judge Sobel from his statistics). Conversations with local law enforce- 
An obvious yet sometimes overlooked aspect of the mass jail break concern also merits mention. Habeas corpus relief rarely means the thrusting onto society of menaces who otherwise would have been permanently incarcerated. Relatively few prisoners are in for life, ${ }^{145}$ and even though habeas corpus relief is usually granted only to very serious offenders, ${ }^{146}$ it still remains true that by the time all state and federal remedies and appeals have been exhausted, most prisoners have relatively little time left to serve. ${ }^{147}$ In practice, habeas corpus often shortens a prisoner's detention minimally.

To summarize, some releases-often of serious offenders-would be inevitable under a policy of full retroactivity. Nevertheless, there is little evidence to indicate that the number of releases under such a policy would be so great as to justify the fears of mass jail break.

\section{An Alternate Theory of Retroactivity and Habeas CoRpus}

Despite all that has been said above, some difficulties would surely result from the upsetting of old convictions. Why then should we apply new criminal procedure standards to release men who received trials in accordance with law as it was then understood, who are probably guilty at least of some offense, and whose guilt is no less certain now than then? Can we continue to reopen old cases in "a perpetual and unreasoned anxiety"148 to achieve perfect justice? Since this article is intended primarily as a critical comment on Professor Mishkin's reliability approach, a fully developed answer will not be presented. Nevertheless, the premises of such an answer will now be suggested.

\section{The Nature of the Rights}

Regardless of whether they affect reliability or personal dignity, newly declared constitutional criminal procedure rights have one im-

ment officials confirm the view that confessions are not as important as had been assumed, particularly in important cases, where thorough investigations by elite officers are made and other evidence is often obtained. According to some of these informants, the need for confessions is greatest in the numerous burglary and larceny cases, where elaborate investigations are uneconomical and where confederates are sought; others stress the importance of confessions in rape cases, in part because of the need for corroboration.

145 See note 140 supra.

146 See Reitz, supra note 126, at 484.

147 Id. at 484-85. The average postconviction proceeding is likely to take approximately two years until all appeals are heard. For disturbed comments about the lengthening time now required for adjudication of habeas corpus petitions, despite the intended promptness and efficiency of this remedy, see Meador, Habeas Corpus and Magna Carta $7 I$ (1966).

148 Bator, supra note 117 , at 453. 
portant characteristic in common: they are constitutional rights, reflecting fundamental norms of the process by which a constitutional democracy goes about the grave and unhappy business of depriving one of its members of his life, his liberty, or his property. Although perhaps not universally valid, ${ }^{149}$ such rights are so fundamental to our legal system as to be a part of our basic charter and immune to ordinary legislative change. ${ }^{150}$ They are not newly created as by legislative enactment, or newly relevant through a change in social or legal circumstances. Their roots go deep in our history, and many have been included in federal and state constitutions since the Revolution. As Professor Kurland has noted, "the Court has not yet withdrawn from the definition of due process ... in Palko ... [as] includ[ing] only those things that are of the very essence 'of a scheme of ordered liberty'." 151 Surely criminal due process principles are no less essential to "ordered liberty" merely because the trials in which they should have been applied occurred some years ago.

Since newly declared constitutional criminal procedure rights "are of the very essence of . . . 'ordered liberty," "states should not be allowed to continue to deprive persons of their freedom on the basis of proceedings now considered contrary to "the kind of fair trial which is this country's constitutional goal."152 The point can best be illustrated by brief examination of some newly declared rights. Thus, if the accusatorial system and the privilege against self-incrimination are indeed of the essence of our system of criminal justice, ${ }^{153}$ was a trial which forced the accused to "shoulder ... [some of the] . . load"154 any less a violation of that system merely because it happened five or even twenty-five years ago? ${ }^{155}$ Did comment on a defendant's failure

149 But see Currier, Time and Change in Judge-Made Law: Prospective Overruling, 51 VA. L. REv. 201, 266 (1965). Such universal validity could not possibly be claimed for the accusatorial nature of our system of criminal justice, although it is one of the system's fundamental aspects. See, e.g., Watts v. Indiana, 338 U.S. 49 , $54-55$ (1949); cf. Palko v. Connecticut, 302 U.S. 319, 325-26 (1937).

150 Kirby v. United States, 174 U.S. 47, 56 (1899).

151 Kurland, Magna Carta and Constitutionalism in the United States: "The Noble Lie," in The Great Charter 48, 68 (1965). A commentator has described due process as referring to rights the violation of which either "shock[s] the conscience of mankind" or is "unfair or uncivilized." Henkin, "Selective Incorporation" in the Fourteenth Amendment, 73 YALE L.J. 74, 76, 78 (1963).

152 Pointer v. Texas, 380 U.S. 400, 405 (1965).

153 Malloy v. Hogan, 378 U.S. 1, 7-8 (1964).

154 Tehan v. United States ex rel. Shott, 382 U.S. 406, 415 (1966).

155 Indeed, despite dicta to that effect, the Court had never held that the states were not required to allow a privilege against self-incrimination. The Court had only held that the no comment rule was not required of the states. See Adamson v. California, 332 U.S. 46 (1947); Twining v. New Jersey, 211 U.S. 78 (1908); Henkin, supra note 151, 
to take the stand do any less damage to the privilege or to the reliability of the fact-finding process then than now? Has it not always been wrong to compel a man to incriminate himself, or to allow him, because of ignorance, to waive his rights either in the police station or in court? Has there even been a time when special handicaps imposed by poverty or race were not fundamentally wrong? Can a trial in which the defendant was deprived of the right of confrontation ever have been fair? Can our legal system ever allow the perpetuation of a conviction based on the kind of "conscience-shocking" conduct found in Rochin v. California? ${ }^{156}$ If it is now said that defendants need a lawyer at every critical stage in the criminal process from interrogation to appeal, has this not always been true? After all, some of the principles of even so controversial a decision as Escobedo are reflected in the statutes of many states. ${ }^{157}$ And even if Escobedo is to be read as requiring the presence of a lawyer from the moment of arrest, is it an especially novel thought that, as a matter of fairness, a man facing an adversary in a legal encounter affecting life and liberty should have the assistance of a lawyer at all critical moments? ${ }^{158}$

The truth is, I think, that recent decisions have not discovered or created new rights; rather, they have only granted new federal remedies for old wrongs. These remedies have been granted only recently not because the rights they protect are newly conceived or newly relevant, but rather because concern for considerations of federalism has lessened ${ }^{159}$ and perhaps because sensitivity to due process problems has increased. But the newness of the remedy does not eliminate the faults of the condemned proceeding, for just as we cannot tolerate the continued imprisonment of a man whose conviction was based on unreliable evidence, so we cannot tolerate the continued imprisonment of a man whose conviction failed in other respects to meet the fundamental legal standards of the community.

The "declaration" of new constitutional criminal procedure rights is thus an illustration of Professor Mishkin's comment in Part I of his article: " $[E]$ ven when 'new law' must be made, it is often in fact a

at 81. Similarly, in Palko the Court did not hold that the states could ignore double jeopardy considerations, but only that the particular statute allowing a state to appeal a criminal conviction was not in violation of principles of ordered liberty. It expressly reserved broader questions. Palko v. Connecticut, 302 U.S. 319, 328 (1937).

156342 U.S. 165, 166, 172-73 (1952).

157 See A.L.I. Model Code of Pre-Arraignment Procedure, App. V (Tent. Draft No. $1,1966)$.

158 See Kamisar, Equal Justice 36-37; Sutherland, Crime and Confession, 79 Harv. L. Rev. 21, 37 (1965); cf. ABA Canons of Professional Ethics, Canon 9, quoted in Escobedo v. Illinois, 378 U.S. 478,487 n.7 (1964).

159 See generally Allen, supra note 139 . 
matter of the court articulating particular clear implications of values so generally shared in our society ... that the process might well be characterized as declaring a preexisting law."160

That the Court itself often views its innovating function from this perspective is evidenced by its persistent efforts to trace the historical roots of the rights it is "declaring." 161 Moreover, there is an element of support for a broad theory of retroactivity in Mr. Justice Clark's intimation in Linkletter that, apart from unreliability, "the abhorrence of society" to coerced confessions is a reason for giving retroactive effect to coerced confession cases. ${ }^{162}$ Since the "abhorrence" alluded to includes "so mild a whip" as was exercised in Haynes, it would appear clearly abhorrent to keep a man in jail when the process of his conviction violated other standards that are essential to ordered liberty.

The Linkletter holding cuts the other way, however, for the Court refused to apply $M a p p$ retroactively on the ground that "the purpose" of Mapp's exclusionary rule was deterrence of police misconduct following the failure of other methods. ${ }^{163}$ Mapp provides some support for the Linkletter. Court's interpretation and also contains language referring to a changed legal environment. ${ }^{164} M a p p$ thus seems tied to current conditions. But these aspects represent only a part of Mapp. ${ }^{165}$ Also present there is the notion of Justices Brandeis and

160 Mishkin 60. This comment was developed from some of Professor Lon Fuller's views.

161 Pointer v. Texas, 380 U.S. 400 (1965), is a particularly good example of both the Court's technique and the fundamental nature of the rights involved. There, the Court held that the sixth amendment's right of confrontation is binding on the states, and requires the exclusion of an out of court statement by a witness who was unavailable at trial. In a unanimous decision, the Court found that a "right of confrontation and cross-examination is an essential and fundamental requirement for the kind of fair trial which is the country's constitutional goal." Id. at 405. Although Justices Harlan and Stewart rejected the majority's incorporation approach, they concurred in finding that "a right of confrontation is 'implicit in the concept of ordered liberty." Id. at 408. The Court rejected prior decisions excluding this right, and relied on Kirby v. United States, 174 U.S. 47 (1899), and more recent cases for authority, stating that "there are few subjects upon which this Court and other courts have been more nearly unanimous than in their expressions of belief" in the fundamental nature of the right of confrontation. Id. at 405. The nature of the right and the language of the Court seem to compel application of Pointer to old trials as well as new, not because we require a higher level of confidence as to guilt, but because the level of confidence that was always required was not met. One court has given Pointer retroactive effect on habeas corpus. McBee v. Weaver, 355 F.2d 445 (6th Cir. 1966).

162381 U.S. at 638 . See text accompanying note 37 supra.

163381 U.S. at 618, 636; Tehan v. United States ex rel. Shott, 382 U.S. 406, 413 (1966). 164 Mapp v. Ohio, 367 U.S. 643, 650-55 (1961). The changed legal environment includes, the elimination of various ways of nullifying the exclusionary rule, such as the "silver platter" doctrine, overruled the term before in Elkins v. United States, 364 U.S. 206 (1960).

165 For doubts about the efficacy of the exclusionary rule as a deterrent, see Allen, 
Holmes in Olmstead,"166 that "the government ought not to use evidence obtained . . . by a criminal act," 167 lest by such use the government ratify the illegality and become a lawbreaker. Through it has rarely been the sole basis for setting aside a conviction, ${ }^{168}$ or excluding improperly obtained evidence, this notion has recurred enough in past cases $^{169}$ to suggest that it reflects something quite fundamental: a link between exclusion and the rule of law.

This link can be illuminated by an analysis of the reasons for the Brandeis-Holmes notion. Traditional wisdom holds the reasons to be that: (1) government criminality breeds citizen criminality; ${ }^{170}$ and (2) courts should not allow themselves to be contaminated with the fruits of "dirty business." 171 Yet, these two reasons seem inadequate to explain today's exclusionary rule, which applies not only to clear and inexcusable abuses-which probably come before the courts today rarely, if ever-but also to good faith technical errors such as mistakes over probable cause, inadequate affidavits, and inadequately descriptive warrants. Such technical errors can hardly have any tendency to breed crime, nor are they such "dirty business" as will "contaminate" the courts in any meaningful sense. ${ }^{172}$

The real reason for the Brandeis-Holmes notion seems to rest on a broad and fundamental principle: in a constitutional democracy of limited powers, a government agency has no authority over an individual except that which is conferred upon it by law; if such authority is exceeded, the fruits of such excess should not be recognized by any branch of government, especially that branch which has the

supra note 139, at 32-34, 37-40. For empirical confirmation of some of these doubts, see LaFave, Improving Police Performance Through the Exclusionary Rule: Part I-Current Police and Local Court Practice, 30 Mo. L. Rev. 391 (1965).

166 OImstead v. United States, 277 U.S. 438 (1928).

167 Id. at 470 . Though Olmstead involved violation of a penal statute, the point is even more applicable to violation of a constitutional provision.

168 Except perhaps in the entrapment cases. See Sorrells v. United States, 287 U.S. 435, 454-56, 459 (1932) (Roberts, J., dissenting); Paulsen \& Kadish, Criminal Law and ITs Processes 903 (1962): "The accused in raising the entrapment question does not argue that he is innocent of criminality, but rather that the courts should not convict him because to do so would be to approve police methods which ought not to be approved." 169 Mapp v. Ohio, 367 U.S. 643, 660 (1961); Rochin v. California, 342 U.S. 165, 173-74 (1952); People v. Cahan, 44 Cal. 2d 434, 445-46, 282 P.2d 905, 911-12 (1955).

170 Olmstead v. United States, 277 U.S. 438, 485 (1928); Collins v. Beto, 348 F.2d 823, $831-32$ (5th Cir. 1965).

171 Allen, supra note 139 , at $20-21$.

172 If we were really concerned only with flagrant abuses, we would adopt the Scottish method and exclude only evidence obtained by abusive means, as suggested by Judge Friendly, supra note 112, at 952. See Hardin, Other Answers: Search and Seizure, Coerced Confessions and Criminal Trials in Scotland, 113 U. PA. L. REv. 165, 167-69 (1964). 
foremost role in furthering the rule of law. ${ }^{173}$ The law sets limits to the state's exercise of power over the individual, and, regardless of mitigating circumstances, a substantial overstepping of those limits should not be legally cognizable. A court sworn to uphold and promote observance of the law cannot adequately perform its function if it ignores illegality in the enforcement of the law.

This is not the place for an extended analysis or defense of the doctrine of "judicial integrity." That its requirements have been observed as often in the breach as in the performance is obvious. ${ }^{174}$ Still, it was clearly an important element in $M a p p$, where relevant parts of the Olmstead dissent were quoted, ${ }^{175}$ and the illegality occasioning its application to search and seizure was established as early as Wolf $v$. Colorado ${ }^{178}$ in 1949. Consideration of the basic principles underlying Mapp and its exclusionary rule thus supports the view that all convictions in which illegally obtained evidence was admitted should be set aside.

To summarize, newly declared constitutional criminal procedure rights are not newly conceived or newly relevant. Rather, they reflect fundamental principles of our legal system-principles implicit in the concept of ordered. liberty. Regardless, then, of when it took place, a trial conducted in a manner inconsistent with these principles should not be permitted to stand.

\section{Some Problems}

Numerous objections to the above outlined theory may be raised: How does upsetting old convictions further the values of due process and the rule of law? Are all constitutional criminal procedure rights really fundamental? What about good faith state reliance on an overruled decision? Does not such a thoery both deny and discourage judicial creativity?

173 Indeed, it should not be legally cognizable by any governmental agency for any purpose, whether such purpose be tax collection, economic regulation, or law enforcement.

174 For example, a defendant will be held for trial even though he was brought into the jurisdiction illegally. Frisbie v. Collins, 342 U.S. 519 (1952). Until Mapp, the common law rule that relevant evidence was admissible regardless of the manner in which it was obtained applied in at least half the states. See Mapp v. Ohio, 367 U.S. 618, 651 (1961). Evidence obtained illegally by private persons is still admissible. Burdeau v. McDowell, 256 U.S. 465, 475 (1921). Evidence obtained illegally is admissible before a federal grand jury. West v. United States, 359 F.2d 50 (8th Cir. 1966).

175367 U.S. at 659-60. The Court in Linkletter seems to have misstated the point by regarding it as limited to the problem of disparate federal-state standards. See 381 U.S. at $634-35$.

176338 U.S. 25 (1949). 
To turn first to judicial creativity, the arguments made in the preceding section do not imply that the Court has not been creative or has not been making "new law." The Court has made "new law"-and has done so quite openly and deliberately. But the new law the Court has been making is nothing more-or less-than the application to the states and the federal government of principles of legal morality fundamental to our particular constitutional democracy-the "natural law" of our society, if you will.177 The judge who introduces such principles into the law is no less a creative judge, no less a "lawmaker," merely because he did not first conceive them. ${ }^{178}$ Thus, the view proposed herein is not, I think, uncritical Blackstonianism.

On the other hand, would not complete retroactivity stifle such judicial creativity? Would not the Court be unwilling to declare some new rights if all new rights had to be declared retroactively? ${ }^{\text {179 }}$ This objection, if valid, is entitled to considerable weight, for too much still remains to be done. ${ }^{180}$ There is reason to believe, however, that fears of stifling judicial creativity by complete retroactivity are exaggerated. In the past, when the unsettling effect was most certain and most significant-Gideon v. Wainwright, Jackson v. Denno, Fay v. Noiathe Court did not hesitate. ${ }^{181}$ Is there much reason to expect that it would start hesitating in the future? Moreover, a policy of giving all constitutional criminal procedure decisions retroactive effect might

177 Oaks, Legal History in the High Court: Habeas Corpus, 64 Mrck. L. REv. 451, 459 (1966).

178 Cf. Seavey, Mr. Justice Cardozo and the Law of Torts, 52 HARv. L. REv. 372 (1939).

179 In re Lopez, 62 Cal. 2d 368, 381, 398 P.2d 380, 390, 42 Cal. Rptr. 188, 198 (1965); Brief for the State of New York, supra note 134, at 47-49. It is interesting that such concern is now being expressed by interests which would normally be expected to applaud judicial restraint. Indeed, the approval by prosecutors and their spokesmen of such a legislative device as prospective overruling seems somewhat inconsistent with the complaints by many of these that the Court has been legislating too much.

180 But see the remarks of Professor Bator in Dorsen (ed.), The Proper Role of the United States Supreme Court in Civil Liberties Cases, 10 WAYNe L. REv. 457 (1963).

181 Sce United States ex rel. Angelet v. Fay, 333 F.2d 12, 26 (2d Cir. 1964) (Marshall, J., dissenting), aff'd, 381 U.S. 654 (1965). Although the New York State Brief in Miranda minimizes the Gideon effect on the ground that many states had already provided counsel, few did so to the extent required by Gideon. Furthermore, almost all states have multiple offender laws, and sentences under such statutes even in states which provided counsel are affected by the now invalid convictions in states which did not. United States ex rel. Savini v. Jackson, 250 F.2d 349 (2d Cir. 1957); United States ex rel. Turpin v. Snyder, 183 F.2d 742 (2d Cir. 1950); People v. Kearney, 45 Misc. 2d 1041, 258 N.Y.S.2d 769 (Sup. Ct. 1965); see Greer v. Beto, 86 Sup. Ct. 1477 (1966). In addition, parolees who are returned to prison for parole violations will have an opportunity to raise Gideon and Jackson v. Denno claims which they had obviously not wanted to do earlier. See United States ex rel. Gates v. Pate, 355 F.2d 879 (7th Gir. 1966). Several such Jackson v. Denna claims have recently appeared in Erie County, New York. 
induce state courts-and, perhaps, even local police forces-to try to anticipate future Supreme Court decisions in order to avoid large scale losses of convictions. ${ }^{182}$ Non-retroactive overruling, by contrast, reduces some of this inducement.

But how does the upsetting of old convictions further the purposes of recent constitutional criminal procedure decisions? More particularly, if Professor Mishkin's division of due process purposes into reliability and individual dignity categories is sound, how does retroactivity further those in the latter category? The answer is, I think, that upsetting old convictions promotes the purposes of dignity and integrity in the same way that upsetting new convictions does: in both instances, a community acting in accordance with its conception of the norms "implicit in the concept of ordered liberty" refuses to accept the fruits of the violation of such norms. After all, how is any given defendant's dignity and integrity furthered by the exclusion of illegally obtained evidence, of confessions obtained by coercion or in the absence of counsel, or of statements obtained in violation of the privilege against self-incrimination? In all such applications of the exclusionary rule, the individual defendant's dignity and integrity have already been violated, and the subsequent use of the evidence in court would hardly be a significantly greater violation. Clearly, the protection of individual dignity and integrity in each application comes not from any deterrent effect, ${ }^{183}$ but rather from the fact that state power over the individual is being confined to limits imposed by fundamental due process concepts. ${ }^{184}$

Can it realistically be said, however, that all of the facets of all the rights recently imported into the due process clause are truly fundamental? Is it not true that although "some specifics of the Bill of Rights, in all their manifestations, may indeed be 'process' which is required by the conscience of mankind; others may not"? 185 Are, for example, all of the twists and turns of federal search and seizure law,

182 In the Buffalo, N.Y., police training program, policemen are advised to warn a suspect before interrogation in order to avoid the impact of a retroactive overruling of People v. Gunner, 15 N.Y. 2d 226, 205 N.E.2d 852, 257 N.Y.S.2d 924 (1965), which held admissible statements obtained by police after arrest and before counsel had appeared even though the defendant had not been advised of his rights.

183 Even Professor Mishkin eschews this viewpoint. See Mishkin 90 n.126. I do not deny the great importance of deterrence as one basis for these rules, but it is not the only factor. Even if exclusion were not the best or even a good deterrent, convictions obtained by improper methods should still not be allowed to stand.

184 Walker, The Constrtutional and Legal Development of Habeas Corpus as the WRIT OF LIBERTY 86 (1960).

185 Henkin, supra note 151 , at 78. 
or all the ramifications of the privilege against self-incrimination, fundamental? ${ }^{186}$

The short answer to these questions is that the Court evidently thinks so, for it has retained the language of $\mathrm{Palko}^{187}$ and has rejected almost all attempts to impose lesser standards on the states. ${ }^{188}$ But short answers are not always good answers, especially where the questions are basic. Perhaps a fuller answer is that a policy of selective incorporation of only some aspects of due process rights would raise the same problem that Betts $v$. Brady ${ }^{189}$ did: the necessity of frequent decisions on hard issues, with the likelihood of wide differences of opinion over the proper choices to be made. Indeed, are there objective criteria for determining the fundamental nature of the various aspects of the right to counsel? Of the right to be free from an unannounced entry? Of the no comment rule? What are the factors that are clearly decisive as opposed to being merely relevant? ${ }^{190}$ It seems to me easier and in the long run less abrasive simply to deem all facets of all constitutional rights fundamental. The detriment to state sovereignty resulting from the extension of federal protection to possibly marginal facets is more than compensated for by the benefits of greater certainty and reduced friction flowing from a policy of nondifferentiation among facets. ${ }^{101}$

What about state reliance on overruled decisions, a consideration that clearly influenced the Court's actions in Linkletter, Griffin, and Tehan? All too often, state reliance does not merit protection. Unreasonable state searches and seizures were condemned as early as 1949 in Wolf, and any state reliance on the belief that misconduct would not be disciplined was unjustified. For years legislators, judges, prosecutors, and police ignored obvious problems of the availability of counsel, the coercion of confessions, the admission of self-incriminatory statements, and the special needs of indigent defendants: with respect at least to these areas, it can fairly be said that the Supreme Court gave the states time to put their own houses in order and that the states failed to do so. And in many cases, Escobedo being only one

186 Cf. Elkins v. United States, 364 U.S. 206, 238-39 (1960) (Frankfurter, J., dissenting).

187 Palko v. Connecticut, 302 U.S. 319 (1937).

188 See, e.g., Pointer v. Texas, 380 U.S. 400, 413 (1965) (Goldberg, J., concurring); Malloy v. Hogan, 378 U.S. 1, 10-11 (1964). But see Henry v. Mississippi, 379 U.S. 443, 449 n.6 (1965), noting that the Court has not yet decided whether the federal search and seizure rules apply in full to the states.

189316 U.S. 455 (1942).

$190 \mathrm{Cf}$. Bok, The Tampa Electric Case and the Problem of Exclusive Arrangements Under the Clayton Act, 1961 SuP. Cr. REv. 267, 275.

191 See Kalven, The Metaphysics of Obscenity, 1960 Sup. Cr. REv. 1, 25. For a contrary view see Friendly, supra note 112, at 935-38. 
example, the state's own laws were violated. ${ }^{192}$ On such a record, it is difficult to see that state reliance merits protection.

Nor is it clear who would be harmed by complete retroactivity. State judges might be offended, but they certainly would not be harmed. Policemen and prosecutors have indeed prepared cases in reliance on prior law and thus overlooked or rejected evidence they might otherwise have used, ${ }^{193}$ but they certainly would not become subject to criminal liability ${ }^{194}$ or loss of personal reputation. States would, of course, lose some convictions, but, as has already been indicated, ${ }^{195}$ the probable magnitude of this phenomenon is often exaggerated. And as for the time and expense of hearings and retrials which would be necessitated by a policy of complete retroactivity, suffice it to say that when the preservation of individual liberties has been at stake, the Supreme Court has rarely based its judgments on considerations of time and expense. ${ }^{196}$

Still, is there not a need for stability and "predictability" in the law? Is it not true that "a holding of retroactivity would necessarily draw into question the value of ... [the Supreme Court's] decisions as a guide for future conduct"? 197 This view, of course, conflicts with the earlier one, expressed by the very same voices, that complete retroactivity will stifle judicial creativity and discourage "the future development of progressive solutions to the difficult problems of criminal procedure"; 198 after all, such "development" will also "draw into question the value of ... [the Supreme Court's] decisions as a guide for future conduct." This inconsistency perhaps confirms the earlier suggestion that no necessary connection exists between judicial creativity and retroactivity. In any event, the revolution in constitutional criminal procedure is not yet over, and instability and unpredictability will be with us for some time to come. Complete retroactivity is thus not likely to produce a significantly greater amount of doctrinal or

192 See text accompanying note 157 supra; Kamisar, Equal Justice 56.

193 Brief for the State of New York, supra note 134, at 42.

194 Note, Prospective Overruling and Retroactive Applications in the Federal Courts, 71 YALE L.J. 907, 920-21 (1962); cf. James v. United States, 366 U.S. 213, 221 (1961).

195 See text accompanying notes 134-44 supra.

196 See Jackson v. Denno, 378 U.S. 368 (1964); Gideon v. Wainwright, 372 U.S. 335 (1963); Eskridge v. Washington, 357 U.S. 214 (1958). The expenses involved in both future and retroactive applications of Gideon, and for future compliance with $M a p p$, is likely to make any additional-and quite temporary-expense for retroactive application of Mapp, Griffin, and Escobedo quite minor.

197 Brief for State of New York, supra note 134, at 45 .

198 Id. at 47-49. See text accompanying notes $177-178$ supra. 
other instability than will partial retroactivity under the reliability theory.

\section{CONCLUSION}

In response to Professor Mishkin's question, the reasons for upsetting old convictions on the basis of new constitutional doctrines come down to this: new constitutional doctrines are not new conceptions but rather reflections of principles of "ordered liberty" fundamental to our legal system. Such principles are equally applicable to past and present trials, for an ethical society cannot seek to retain the fruits of past defaults.

This is not to deny that complete retroactivity involves many theoretical and practical difficulties. Many of the problems frequently linked to complete retroactivity seem to be, however, pseudo-problems, and the others seem fewer and less troublesome than those created by Professor Mishkin's theory. Complete retroactivity is at least consistent with the nature of newly declared constitutional rights, and it neither ignores the present role of habeas corpus nor creates gross inequities.

\section{EPILOGUE}

Long after this paper had been submitted for publication, the Supreme Court handed down its decisions in Miranda v. Arizona ${ }^{199}$ and Johnson v. New Jersey. ${ }^{200}$ In the first, the Court went considerably beyond both Escobedo and the facts of the four cases before it and set down detailed guidelines designed to protect a suspect's fifth amendment privilege against the "compulsion inherent" in custodial interrogation. A week later the Court narrowly restricted the backward thrust of both Miranda and Escobedo: because it was not the "prime" or "basic" purpose of either case to improve the reliability of the factfinding process, the rulings were held applicable only to those cases in which the trials began after June 13, 1966, and June 20, 1964, the respective dates of the Miranda and Escobedo decisions.

The specific holding in neither case was very surprising. It was expected that the Court would reaffirm and expand Escobedo, and once Miranda was decided as a fifth amendment case, its purely prospective application was predictable. ${ }^{201}$ What was surprising about

19986 Sup. Ct. 1602 (1966). Justices Harlan, Clark, Stewart and White dissented.

20086 Sup. Ct. 1772 (1966). Justices Black and Douglas dissented.

201 See text accompanying note 78 supra. 
both cases was the sweep of the Court's holdings and mandates. I think it fair to say that no one expected the Court in Miranda to issue an opinion which tried to decide virtually every question of law that was likely to arise ${ }^{202}$ or to mandate a detailed set of operational procedures; and few, if any, expected the Court to deny the benefits of Miranda and Escobedo to cases still on direct appeal.

This Epilogue will briefly review the Johnson decision in terms of its impact on the earlier discussion. Touched on will be: (I) the "prime" or "basic purpose" test of reliability adopted by the Court; (2) the refusal to apply Escobedo and Miranda to cases on direct review; and (3) the relation of Miranda and Escobedo to the alternate theory of retroactivity set out above.

\section{The Decisions}

In Miranda, the Court held that the privilege against self-incrimination can be protected against the inherent coerciveness of custodial interrogation only if the suspect is effectively advised of his right of silence and ensured an opportunity to exercise that right. Accordingly, the police are now required to precede each interrogation of a person in custody, or otherwise deprived of his liberty, with a four-fold warning:

He must be warned prior to any questioning that he has the right to remain silent, that anything he says can be used against him in a court of law, that he has the right to the presence of an attorney, and that if he cannot afford an attorney one will be appointed for him prior to any questioning if he so desires. ${ }^{203}$

202 Thus the Court applied its ruling not only to custodial interrogation but to all interrogations where the accused is deprived of his liberty, 86 Sup. Ct. at 1612, to exculpatory as well as to incriminating statements, $i d$. at 1629 , and to waivers obtained by deception or cajolery, ibid. It also granted a right to assigned counsel in cases of indigency, $i d$. at 1626-27; established the burden of proof in waiver cases, $i d$. at 1628; indicated instances where a finding of waiver would be set aside, id. at 1629; announced a right to withdraw a waiver, $i d$. at 1628 , contrary to the rule in certain other contexts, see Rogers v. United States, 340 U.S. 367 (1951) (grand jury witness); 86 Sup. Ct. at 1628 n.45; reaffirmed that denying a lawyer the right to consult with his client violated the sixth amendment, $i d$. at $1623 \mathrm{n.35}$; and dealt with spontaneous declarations and with the questioning of on-the-scene witnesses, id. at 1629-30. Almost none of these rulings was necessary to the disposition of the cases before the Court.

203 Id. at 1630. The Court repeated this statement in substantially the same form several times in the opinion. The first time it did so, however, it defined the "custodial interrogation" requiring the warning "to mean questioning initiated by law enforcement officers after a person has been taken into custody or otherwise deprived of his freedom 
After this warning, the defendant can waive his rights but the prosecution must prove that such a waiver was knowing and intelligent; moreover, the waiver may be withdrawn at any time merely by a refusal to answer any more questions, or by a request for a lawyer. No pressures, trickery, or cajolery may be used to obtain a waiver, and the prosecution has the same heavy burden of proof of waiver as in the waiver of counsel cases. ${ }^{204}$ Further, the Court stressed that the specific procedures suggested in its opinion need not be followed provided there are available other equally effective methods for apprising a suspect of his right of silence and for ensuring the opportunity for its exercise. ${ }^{205}$

In Johnson, which had originally raised only the question of the retroactivity of Escobedo, the Court dealt with the week-old Miranda decision as well. Reaffirming the three-fold test applied in Linkletter and Tehan, ${ }^{206}$ the Court denied retroactivity to both Miranda and Escobedo because their "prime purpose" (elsewhere in the opinion called "basic purpose"), is not to "ensure the reliability of the factfinding process," but "to guarantee full effectuation of the privilege against self-incrimination, the mainstay of our adversary system of criminal justice." 207 Though the opinion noted several times that Miranda and Escobedo did indeed "guard against the possibility of unreliable statements in every instance of in-custody interrogation, they encompass situations in which the danger is not necessarily as great as when the accused is subjected to overt and obvious coercion." 208 The effect of a constitutional rule on reliability, noted the

of action in any significant way." Id. at 1612. It dropped a footnote to explain: "This is what we,meant in Escobedo when we spoke of the investigation which had focused on the accused." Id. at 1612 n.4. Elsewhere in the opinion, however, the Court omitted the qualifier "significantly" in referring to the restraint requiring a warning and referred simply to "deprived of his freedom of action," $i d$. at 1624, "freedom of action is curtailed," ibid, and "otherwise deprived of his freedom," id. at 1630. The qualifier could make a difference in deciding whether warnings have to be given prior to field investigations, such as under New York's "Stop and Frisk" law. N.Y. CodE CRIM. Proc. § 180-a; see LAFAve, ARREst 344-47 (1965).

204 Carnley v. Cochran, 369 U.S. 506, 516 (1962); Johnson v. Zerbst, 304 U.S. 458 (1938). Proof of prolonged or incommunicado interrogation would be strong evidence against a finding of waiver. 86 Sup. Ct. at 1629.

205 Id. at 1624.

206 "We must look to the purpose of our new standards governing police interrogation, the reliance which may have been placed upon prior decisions on the subject, and the effect on the administration of justice of a retroactive application of Escobedo and Miranda." 86 Sup. Ct. at 1777.

207 Id. at 1779.

208 Ibid. 
Court, is a question of "degree," of "probabilities," and "of the extent to which other safeguards are available to protect the integrity of the truth-determining process at trial."209 As one such other safeguard, the Court emphasized that the case law on coerced confessions is still available to past defendants, and that this test "has become increasingly meticulous through the years. ... Thus, while Escobedo and Miranda provide important new safeguards against the use of unreliable statements at trial, the non-retroactivity of these decisions will not preclude persons whose trials have already been completed from invoking the same safeguards as part of an involuntariness claim."210

With respect to state reliance, the Court declared that law enforcement agencies had justifiably relied on Crooker $v$. California ${ }^{211}$ and Cicenia v. Lagay, ${ }^{212}$ which were good law until Escobedo and Miranda, unlike the Wolf-Mapp situation, in which the authorities knew that they were forbidden from making unconstitutional searches. Moreover, retroactivity would seriously disrupt the administration of justice by requiring retrials or releases of "numerous prisoners found guilty by trustworthy evidence in conformity with previously announced constitutional standards." 213 The Court then concluded that all of these reasons also justified limiting the retroactivity of Escobedo and Miranda to trials begun after the decisions were announced. ${ }^{214}$ It noted, however, that the states were of course free to adopt a more liberal rule. ${ }^{215}$

\section{A. Reliability as the Necessary "Prime Purpose"}

The policies and practicalities which militate against using reliability as the principal criterion for retroactivity have already been discussed. Some of the practical difficulties pointed out earlier, which stem from Professor Mishkin's requirement that reliability be an intended effect of the particular rule announced, are compounded by the Court's requirement that reliability be the prime or basic purpose of the specific rule announced. The Court's new formulation would seem to require a two-fold inquiry: (1) a subjective analysis to ascer-

209 Ibid.

210 Ibid. In this connection, the Court cited Davis v. North Carolina, 86 Sup. Ct. 1761 (1966), a voluntariness case decided the same day.

211357 U.S. 433 (1958).

212357 U.S. 504 (1958).

21386 Sup. Ct. at 1780 .

214 Ibid.

215 Id. at 1781. 
tain the prime or basic purpose; and (2) an objective analysis of the probability and degree to which the new rule enhances reliability, taking into account "the extent to which other safeguards are available to protect the integrity of the truth-determining process at trial." 216 The first is an extremely difficult task, for constitutional rules often have many purposes, and it is often exceedingly difficult to determine a rule's prime or basic purpose. ${ }^{217}$ The second, obviously related to the first, involves balancing several uncertain and disputable factors, similar to the procedure which was required by the now discarded Betts $\boldsymbol{v}$. Brady test. ${ }^{218}$ Moreover, the Court expressly requires this delicate double judgment to be made with respect to each facet of each constitutional right, thus vastly increasing the number of situations in which such a judgment will be necessary. ${ }^{219}$ As Professor Mishkin has noted in another context, so large a number of retroactivity issues will keep the state and federal courts busy with difficult retroactivity problems for some time to come. ${ }^{220}$ Though problems should not be avoided simply because they are hard or numerous, these factors cannot be ignored when considering the rule's impact on the administration of justice.

Moreover, why give retroactive effect to a rule only when its "prime" or "basic purpose" is to enhance reliability? Is it not enough that the rule in question substantially improves reliability, even if such im-

216 Id. at 1779 .

217 See text accompanying note 109 supra; Mishkin 81 n.85, 90 \& n.126. The difficulty can be seen in the Court's swift judgment as to Escobedo's basic purpose. In Johnson, the Court took about five sentences to decide that the "basic purpose" of both Escobedo and Miranda was to protect the fifth amendment privilege. 86 Sup. Ct. at 1779. But in Miranda, the Court intimated that Escobedo might have separate significance as establishing a sixth amendment right of counsel in the police station. See 86 Sup. Ct. at 1623 n.35; note 243 infra. The Court left a good deal of uncertainty as to the role counsel might play under the sixth amendment, so that it is difficult and probably premature to conclude what the "basic" or "prime" purpose of such a right would be. Cf. Note, The Curious Confusion Surrounding Escobedo v. Illinois, 32 U. CHI. L. REv. 560 (1965). It can hardly be done adequately in a few lines.

218316 U.S. 455 (1942).

219 See text accompanying note 109 supra.

220 Mishkin 65 n.35. A glance at a few recent advance sheets already discloses a substantial number of cases raising retroactivity issues in many different contexts. See, e.g., United States ex rel. Romano v. Fay, 360 F.2d 389 (2d Cir. 1966) (retroactivity of Massiah); Nance v. United States, 359 F.2d 273 (D.C. Cir. 1966) (retroactivity of requirement of counsel at preliminary examination); Haggard v. Henderson, 252 F. Supp. 763 (M.D. Tenn. 1966) (retroactivity of state rule forbidding prejudicial joinder of habitual criminal and other charges); Mordecai v. United States, 252 F. Supp. 694 (D.D.C. 1966) (retroactivity of requirement of counsel in Juvenile Court waiver proceedings). 
provement is not the prime purpose, or even intended at all?221 In other words, should not the purely objective half of the Court's test be sufficient? If such a standard, or even Professor Mishkin's partly subjective "an intended effect" test, were applied, the Court's own language would clearly support retroactivity for Miranda and Escobedo. In Johnson, the Court conceded that these cases provided important and intended "safeguards against the use of unreliable statements at trial." 222 And in discussing reliability in Miranda, the Court expressly and unambiguously declared:

That counsel is present when statements are taken from an individual during interrogation obviously enhances the integrity of the fact-finding processes in court. The presence of an attorney, and the warnings delivered to the individual, enable the defendant under otherwise compelling circumstances to tell his story without fear, effectively, and in a way that eliminates the evils in the interrogation process. Without the protections flowing from adequate warnings and the rights of counsel, "all the careful safeguards erected around the giving of testimony, whether by an accused or any other witness, would become empty formalities in a procedure where the most compelling possible evidence of guilt, a confession, would have already been obtained at the unsupervised pleasure of the police." 223

In Johnson, the Court did stress that there are other reliability safeguards, particularly the continuing availability of the "increasingly meticulous" voluntariness standards. But one of the most important reasons for the decision in Miranda was that the secrecy of the interrogation room precluded a meaningful implementation of those voluntariness standards. ${ }^{224}$ Moreover, the Court itself answered this point in Miranda when it declared that without "adequate warnings and the rights of counsel ... 'all the careful safeguards . . . become empty formalities," "'225

\section{B. Denial of Retroactivity to Cases on Direct Review}

Probably the most novel aspect of Johnson was the Court's decision to limit the effect of Miranda and Escobedo to those cases in which

221 Cf. Professor Mishkin's analysis of the coerced confession cases, Mishkin 83-85, and of Griffin v. Illinois, 351 U.S. 12 (1956), Mishkin 82-83.

22286 Sup. C. at 1779.

22386 Sup. C.t. at $1623-24,1626$.

224 Id. at $1612-13,1614$.

$225 I d$. at 1624. For a discussion of how counsel can improve the reliability of the process, see text accompanying notes 102-07 supra. 
trials began after the respective decisions, while leaving the LinkletterTehan direct review rule in effect for the latter situations. The Johnson choice of a trial date cut-off implicitly rejects Professor Mishkin's theoretical distinction between direct review and collateral attack as a basis for deciding retroactivity. However, while Professor Mishkin presented a carefully reasoned argument for his theory, applicable to all cases and based on a traditional and plausible distinction, the Court presented virtually no reasoned analysis for either the LinkletterTehan or Johnson dividing lines. As noted earlier, Linkletter and Tehan contained almost no justification for their particular cut-off points although the Johnson opinion explained that "decisions prior to ... [those cases] had already established without discussion that Mapp and Griffin applied to cases still on direct appeal at the time they were announced." 228 With respect to Escobedo and Miranda, the Court said only that it would be unfair to the authorities to impose the new rules on prior cases, for they had not had fair notice of such obligations prior to the decisions. ${ }^{227}$

Although it is easy to criticize any cut-off point, the Court's choices in Johnson seem particularly arbitrary, especially in view of the different choices made in Linkletter and Tehan. Ironically, insofar as good faith reliance is concerned, the Court's rule in Johnson seems much more appropriate to the Griffin-Tehan situation.228 The significant official conduct there was official comment during trial. In trials held before April 28, 1965, the date Griffin v. California was decided, there was every reason to believe such comment was appropriate, and if good faith reliance was to be protected, only comments in trials held after that date should have been "penalized." On the other hand, the most relevant official conduct in Escobedo and Miranda situations occurs during the pre-trial interrogation process and consistent protection of official reliance on prior law would require that Escobedo and Miranda not be applied to cases in which police conducted interrogations before the respective dates of those decisions, regardless of the trial dates. In short, if justified reliance by those state officers most directly affected is the controlling consideration, the particular cut-off dates chosen by the Court seem somewhat inappropriate. ${ }^{229}$

22686 Sup. Ct. at 1780 .

227 Ibid.

228 In fact, as noted earlier, Griffin v. California, 380 U.S. 609 (1965), upset the only reliance which truly merited protection. See text accompanying note 192 supra.

229 For the contention that state officials' reliance should be ignored because such officers will not suffer any meaningful damage from retroactivity, see text accompanying notes $193-95$ supra. 
The announced cut-off date also imposes serious inequities on defendants similarly placed, for it puts a premium on fortuities. For many, the availability of Miranda and Escobedo will ultimately depend on such frustratingly inconsequential matters as the congestion of trial dockets and attorneys' schedules; in some cases co-defendants whose trials were severed will receive radically different treatment. We undoubtedly will also face the prospect of mistrial motions by defendants who were on trial on June 13, 1966, and who thereby hope to bring their cases within the scope of the new rule. Undoubtedly the most pronounced inequity is caused by giving particular petitionerslike Escobedo and Miranda-the benefits of a new rule while withholding it from others whose cases were still on direct review when the rule was announced. ${ }^{230}$ It was widely known that a decision elaborating Escobedo was imminent, most convicted defendants affected by that case appealed and raised the issue, and it was mere accident that Miranda, Vignera, Westover, and Stewart were fortunate enough to have their cases chosen by the Court. Indeed, on the same day Johnson was decided, the Court denied certiorari in over 120 cases raising issues similar to Miranda, many of which were on direct review. ${ }^{231}$

With respect to cut-off dates for future innovating decisions, the Court's failure in Johnson to articulate any reason uniquely relevant to the choices made, indicates that it may generally adopt the trial date approach.

Cut-off dates are always harsh to some, but there is usually either a good reason for the date chosen or no good reason for a different date. Neither of these explains the Court's choice in Johnson. ${ }^{232}$

\section{Retroactivity for Miranda and Escobedo}

The main text of this article has already set forth most of the reasons why both Miranda and Escobedo should be given retroactive effect, but a few points may be worth adding.

With respect to Miranda, it should be noted that insofar as that decision sets out essential constitutional requirements, it is limited to a few matters: (1) the privilege applies in full to custodial interroga-

230 See Bender, The Retroactive Effect of an Overruling Constitutional Decision: Mapp v. Ohio, 110 U. PA. L. REv. 650, 673-79 (1962).

231 See 34 U.S.L. WeEk 3429-31 (June 21, 1966).

232 See CAFN, The SENSE OF INJUSTICE 14-15 (1949): "The arbitrary, though indispensable to many of law's daily operations, is always suspect; it becomes unjust when it distinguishes between indistinguishables." For elaboration of other inequities, see text accompanying note 70 supra. 
tion; (2) a suspect must be apprised of the privilege; and (3) he must be given an unfettered opportunity to exercise it. The specific fourfold warning and counsel procedure set out by the Court is merely one type of protection and is not indispensable if the privilege can be shown to have been otherwise protected. ${ }^{233}$ Thus, complete retroactivity for newly enunciated constitutional rights ${ }^{234}$ would require retroactivity only for the principle that a knowing and free exercise of the privilege must be adequately protected and-by implicationthat any statement taken in the inherently coercive atmosphere of custodial interrogation must be shown to have resulted from a knowing and intelligent waiver.

This basic constitutional doctrine announced in Miranda is novel only insofar as it is now being effectively implemented for the first time. ${ }^{235}$ As the Court was at pains to emphasize: (1) the privilege which the decision seeks to protect is and always has been considered to be essential to the operation of our accusatorial system and to ensuring respect for human dignity; ${ }^{236}$ (2) it has deep historical roots, even with respect to custodial pretrial questioning, for its policies have been reflected in the state voluntariness cases and in such federal decisions as Bram v. United States; ${ }^{237}$ (3) the privilege must be protected in order to ensure a fair trial, and to ensure the integrity of the fact-finding processes in court; ${ }^{238}$ (4) the privilege is seriously jeopardized by the inherently coercive atmosphere of custodial interrogation, especially if the defendant is held incommunicado and not advised of his rights. ${ }^{239}$

Since these rights are so fundamental and deep rooted, how can we, in justice, deny their full benefit to those whose trials antedated June 14,1966 ? The injustice is aggravated by the high probability that in many cases these rights were in fact violated, as the Court's catalogue of police stratagems makes clear. Indeed, if the Court is correct in

23386 Sup. Ct. at 1624 . The defendant has the right to have a lawyer "during the interrogation under the system for protecting the privilege we delineate today." Id. at $1624,1626$.

234 See pp. $747-57$ supra.

235 Almost 60 years ago, a New York judge called upon the legislature to require police to warn defendants of their rights to avoid the danger that confessions would be induced by fear. People v. Randazzio, 194 N.Y. 147, 159, 89 N.E. 112, 117 (1909) (Bartlett, J., concurring).

23686 Sup. Ct. at 1611, 1619.

237168 U.S. 532 (1897). See 86 Sup. C.t. at 1621.

238 Id. at $1623-24$.

239 Id. at 1612-19. 
asserting that unless protective devices are provided, no statement taken under the "compulsion inherent in custodial surroundings ... can truly be the product of free choice," there must be a presumption of compulsion for such protective devices were rarely provided. Finally, does it make sense to grant retroactivity to new voluntariness standards, which are explicitly intended to prevent encroachments on the privilege, while denying retroactivity to Miranda's constitutional core, which is aimed at precisely the same encroachments?240

As for the retroactivity of Escobedo, courts may well be in some confusion as to exactly what it is that they are to apply to cases in which the trials began in the interim between Escobedo and Miranda. Though the Court found that the "basic purpose" of Escobedo was to protect the fifth amendment privilege, it did nothing to dispel the uncertainty as to when Escobedo would be deemed violated. ${ }^{241}$ More specifically, it failed to indicate how many of the five elements in the Escobedo holding were crucial to the decision. ${ }^{242}$ For trials begun during the two years after Escobedo and before Miranda, it is thus uncertain, for example, whether the absence of a preliminary warning will suffice to nullify a confession by a defendant in custody. ${ }^{243}$

240 The continuing availability of the "increasingly meticulous" voluntariness standards which, according to the Court, raise no issue of retroactivity, may draw some of the sting of Johnson, for it may well allow retroactivity to many claims which are not eligible for Miranda relief. The significant question is how much more stringent the voluntariness standards will become. They are never likely to reach the point where a defendant need only show either the absence of one of the four required warnings, or the lack of strong evidence of waiver, which is all that Miranda requires. But the Court may not be through refining voluntariness. In both Johnson and Davis v. North Carolina, 86 Sup. Ct. 1761 (1966), decided the same day, the Court stressed that the absence of some of the safeguards mandated by Miranda, such as advice about the privilege, or access to outside assistance, would be "a significant factor in considering the voluntariness of statements later made." 86 Sup. Ct. at 1764. If the conjunction of these two factors is sufficient to preclude a finding of voluntariness, then many prisoners-probably including Messrs. Johnson and Cassidy-will have their convictions set aside, because, until recently, relatively few police departments have been giving warnings and even fewer have allowed access to outside assistance from friends, relatives, or counsel. See Johnson v. New Jersey, 86 Sup. Ct. 1772, 1775-76 (1966); Davis v. North Carolina, 86 Sup. Ct. 1761 (1966); People v. Taylor, 16 N.Y.2d 1038, 213 N.E.2d 321, 265 N.Y.S.2d 913 (1965); People v. Hocking, 15 N.Y.2d 973, 207 N.E.2d 528, 259 N.Y.S.2d 859 (1965).

241 For some of the uncertainties, see authorities cited at note 76 supra and accompanying text.

242 " $[\mathrm{T}]$ he investigation is no longer a general inquiry into an unsolved crime but has begun to focus on a particular suspect, the suspect has been taken into police custody, the police carry out a process of interrogations that lends itself to eliciting incriminating statements, the suspect has requested and been denied an opportunity to consult with his lawyer and the police have not effectively warned him of his absolute constitutional right to remain silent ..." 378 U.S. at $490-91$.

243 Compare People v. Dorado, 62 Col. 2d 338, 398 P.2d 361 (1965), with People v. 


\section{A Concluding Comment}

Johnson v. New Jersey seems to be an intensely practical decision by a Court which was attempting to forestall an overly-hostile public reaction to Miranda and which was troubled by the possibility of a wholesale release of many guilty men. ${ }^{244}$ But these considerations should not have influenced the Court so decisively. The courts, the police, and the public would have learned to live with the effects of retroactivity, as they have done with so many other vociferously berated decisions. Moreover, the very arbitrariness of the particular cut-off dates chosen, coupled with the widely accepted belief that the decision was in fact based on practical considerations, ${ }^{245}$ reinforces the appear-

Gunner, 15 N.Y.2d 226, 203 N.E.2d 913, 252 N.Y.S.2d 659 (1965). The definition of focus seems to be settled. See Miranda v. Arizona, 86 Sup. Ct. 1602, 1612 n.4 (1966); note 203 supra. As to the future role of Escobedo, the significant question is whether it retains any vitality as the basis for an independent and significant right to counsel in the police station. At one point in Miranda, the Court expressly states that in Escobedo the Court sought a protective device for the privilege, 86 Sup. Ct. at 1623, and, at another point, that the role of counsel at trial is different from that in the interrogation room, id. at 1626. And in Johnson, the Court seemed to treat Escobedo as if it were little more than a weaker Miranda. See 86 Sup. Ct. at 1781 . These statements may imply a narrow scope for Escobedo. But elsewhere, the Court noted that refusal to allow Escobedo's attorney to consult with him deprived Escobedo of an independent sixth amendment right to counsel, citing the New York case of People v. Donovan, 13 N.Y.2d 148, 193 N.E.2d 628, 243 N.Y.S.2d 841 (1963), which Escobedo had also cited. 86 Sup. Ct. at 1623 n.35. And, at still another point, the Court stated that the adversary system begins at the point of custody. $I d$. at 1629. Compare the second formulation of the holding in Escobedo, 378 U.S. at 492. These latter points reaffirm a separate sixth amendment right to counsel at the police station or whenever there is a deprivation of liberty. Moreover, the "critical stage" doctrines of Hamilton, White, Massiah, and Escobedo itself are still relevant and applicable. Indeed, the Court's decision in Schmerber v. California, 86 Sup. Ct. 1826 (1966), may make the pre-trial stage and counsel's pre-trial role even more critical. There, the Court held that certain investigative procedures such as a blood test under certain reasonable circumstances, a line-up, and other attempts to obtain physical evidence from the accused were permissible. Since this power is carefully circumscribed, 86 Sup. Ct. at 1835-36, it will be especially important to have counsel present to ensure that the limitations are observed, especially if there are controversies as to the procedures employed. Thus, the Court has probably left the door open to a right to counsel at the police station independent of the need to protect the fifth amendment privilege. See Note, The Curious Confusion Surrounding Escobedo v. Illinois, 32 U. CHI. L. REv. 560 (1965) and text accompanying notes 93-107 supra. If so, the pressures and needs for such assistance apart from protection for the privilege, and the thrust of Gideon, Douglas and Hamilton, will preclude limiting it to the man with retained counsel who calls at the station. The Court may then have to make a further analysis to find another "basic purpose" for Escobedo.

244 See text accompanying note 142 supra.

245 For one such reaction, see Wall St. Journal, Editorial, July 1, 1966, p. 10. See generally text accompanying notes 6 \& 21-22 supra. 
ance of the Court as a legislative chamber, with all the potential strains that such an appearance creates. When high principle is at stake, this appearance is worth risking. However, it is much less acceptable when no such principle is involved and the result only compounds inequity. 